\title{
Conversion of the OmpF Porin into a Device to Gather Amyloids on the $E$. coli Outer Membrane
}

\author{
Sol Vendrell-Fernández, Paloma Lozano-Picazo, Paula Cuadros-Sánchez, María M. Tejero-Ojeda, \\ and Rafael Giraldo*
}

Cite This: https://doi.org/10.1021/acssynbio.1c00347

Read Online

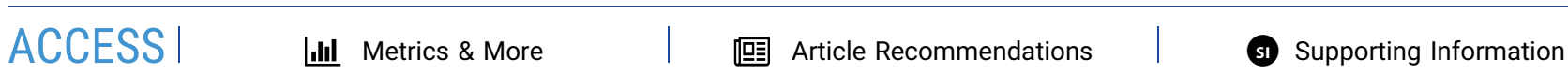

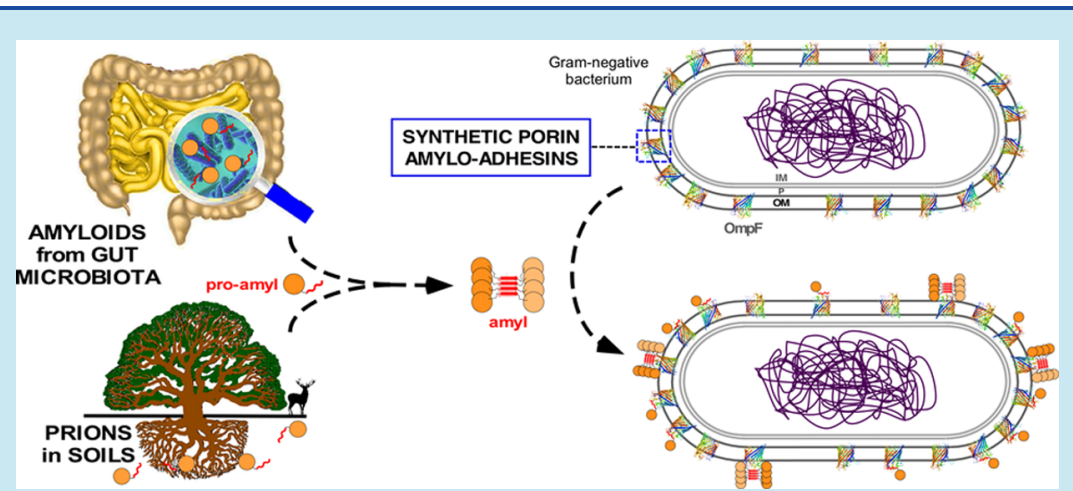

ABSTRACT: Protein amyloids are ubiquitous in natural environments. They typically originate from microbial secretions or spillages from mammals infected by prions, currently raising concerns about their infectivity and toxicity in contexts such as gut microbiota or soils. Exploiting the self-assembly potential of amyloids for their scavenging, here, we report the insertion of an amyloidogenic sequence stretch from a bacterial prion-like protein (RepA-WH1) in one of the extracellular loops (L5) of the abundant Escherichia coli outer membrane porin OmpF. The expression of this grafted porin enables bacterial cells to trap on their envelopes the same amyloidogenic sequence when provided as an extracellular free peptide. Conversely, when immobilized on a surface as bait, the full-length prion-like protein including the amyloidogenic peptide can catch bacteria displaying the L5-grafted OmpF. Polyphenolic molecules known to inhibit amyloid assembly interfere with peptide recognition by the engineered OmpF, indicating that this is compatible with the kind of homotypic interactions expected for amyloid assembly. Our study suggests that synthetic porins may provide suitable scaffolds for engineering biosensor and clearance devices to tackle the threat posed by pathogenic amyloids.

KEYWORDS: OmpF, porin loop grafting, amyloid adhesins, homotypic amyloid recognition, amyloid and prion bioremediation, Escherichia coli

\section{INTRODUCTION}

Amyloids are $\beta$-sheet-structured protein aggregates that are involved in prevalent neurodegenerative and systemic diseases but that recently have also been recognized to confer alternative functional states to some proteins. ${ }^{1-3}$ Amyloids have yet a hidden post-life as recalcitrant contaminants in natural environments, such as those associated with microbiota in soils and in the gut. The mammalian prion protein $(\operatorname{PrP})$, when in its infectious assembled conformation $\left(\operatorname{PrP}^{S C}\right)$ and with origin in the excreta and corpses of animals affected by scrapie in sheep and chronic wasting disease in cervids, is persistent in soils constituting an environmental contaminant and a potential zoonotic threat. ${ }^{4,5}$ On the other hand, amyloid fibers scaffolding biofilms common to $\gamma$-proteobacteria, such as curli (CsgA protein) in Escherichia coli, ${ }^{6}$ are a major component among the extracellular proteins secreted by bacteria in the gut. ${ }^{7}$ Recent evidence on the ability of curli amyloids to cross-seed in other proteins the nucleation of cytotoxic amyloid fibers ${ }^{8-12}$ constitutes a matter of concern adding to the emerging clues on a link between gut microbiota, neuroinflammation, $^{12-15}$ and cancer. $^{16,17}$ In view of the challenges posed by the ubiquitous presence of amyloids, a suitable targeting tool that acts as a biosensor of their presence and leads to their neutralization would be of utmost interest.

Synthetic biology (SynBio) of bacterial adhesion is a topic in expansion. Curli fibers have been engineered to modulate the

Received: July 26, 2021 
assembly of multicellular architectures ${ }^{18-20}$ or the harvesting of metal ligands residues that build a precise coordination geometry. ${ }^{21}$ The fusion of the intimin (Neae) domain of autotransporters to single-domain antibodies ( $\mathrm{VHH}, a k a$ nanobodies) is a powerful approach to tailor adhesins on the bacterial surface for the recognition of a given protein sequence, on the basis of the specificity of the antibody variable domains for antigen recognition. ${ }^{22,23}$ However, it is less likely to be operational for binding to large polymorphic supramolecular assemblies such as those built on amyloids, for which the development of conformation-specific full-length antibodies is still challenging. ${ }^{24}$

In Gram-negative bacteria, the outer membrane (OM) constitutes the natural interface of the cell with the outside world; ${ }^{25}$ thus, it might be the platform of choice to implement tools for amyloid management through SynBio. Porins are the major protein components of the $\mathrm{OM}^{26}$ where they fold as $\beta$ barrels embedded across its asymmetric bilayer (phospholipids toward the periplasm and lipopolysaccharide outward), constituting pores that act both as gatekeepers preserving cell integrity and as (relatively) unselective channels for the intake of ions ${ }^{27,28}$ and small molecules (with an upper limit of ca. $600 \mathrm{Da}$ ), including antibiotics. ${ }^{29,30}$ Porins also are receptors for bacteriophages ${ }^{31,32}$ and the channels for the import of bacteriocins. $^{33,34}$ The structural basis for porin insertion and folding into the bacterial $\mathrm{OM}$ by the BAM chaperoning machinery has been recently elucidated, ${ }^{35-39}$ as for the equivalent SAM complex in the mitochondrial OM. ${ }^{40}$ The newest additions to our exhausted antibiotic arsenal against multi-resistant Gram-negative bacteria are peptidomimetic $\beta$ strand-like molecules, ${ }^{41}$ which target BAM. They work either by establishing hydrogen bonds with strand $\beta 1$ in BamA, the core $\beta$-barrel subunit, dumping its closure on the terminal strand $\beta 16,{ }^{42}$ or through binding to some (L4, L6, and L7) of its eight extracellular loops, ${ }^{43}$ thus inhibiting the correct insertion of porins into the membrane.

SynBio of bacterial OM $\beta$-barrel proteins has found inspiration in the CsgG or FapF channels for the secretion of fibrillar pili ${ }^{44,45}$ or in the $\mathrm{N}$-terminal domain of autotransporters. ${ }^{46}$ De novo design of $\beta$-barrels as successions of antiparallel $\beta$-hairpins, self-closing by zipping the first and last $\beta$-strands up, is among the latest accomplishments of protein engineering. ${ }^{47}$ Besides this, the insertion of antigenic peptides in the external loops boosts their immunogenic potential as vaccine candidates, ${ }^{48-50}$ but this often results in the aggregation of the chimeric protein, unable to be properly inserted into the OM, as amyloid-like (often cytotoxic) inclusion bodies. ${ }^{51,52}$

Trying to overcome these limitations, grafting amyloidogenic sequences in the complementarity-determining regions of nanobodies has revealed the potential of homotypic, selfrecognizing amyloid-based devices. ${ }^{53-55}$ A similar strategy inserting hydrophobic amyloidogenic sequences into porin loops is specially challenging, due to the expected generation of local traps in the rugged folding landscape of the porin during the BAM-assisted insertion of $\beta$-strands within the OM. ${ }^{25,56}$ However, among natural porins, Omp-Pst $1 / 2$ in the marine bacterium Providencia stuartii include each an amyloidogenic loop mediating co-axial channel assembly in trans and thus planktonic cell aggregation into floating communities, potentially enabling intercellular communication. ${ }^{57}$ In some pathogenic E. coli strains, porin heterotrimers are used as receptors in contact-dependent bacterial growth inhibition exerted by toxins as CdiA, implicating the extracellular loops L4 and L5. ${ }^{58}$ Therefore, engineering-tailored amyloidogenic loops into a porin of choice might be an attainable goal.

In this article, we report the conversion of the OmpF porin in the OM of $E$. coli into a scavenger of a model amyloid peptide, gaining function as a synthetic amylo-adhesin. More specifically, grafting an amyloidogenic hydrophobic peptide sequence into the fifth extracellular loop in OmpF (L5) enables its homotypic recognition, either by harvesting the peptide on the bacterial OM or by enticing bacteria to attach to a surface functionalized with a protein displaying that peptide. These findings constitute a proof of concept of the potential that engineered OM bacterial porins have as probes for tagging extracellular amyloids in their way toward bioremediation.

\section{RESULTS AND DISCUSSION}

Expression of OmpF Variants with an Amyloidogenic Stretch Grafted into Extracellular Loops. The E. coli OM porin OmpF (an antiparallel 16-stranded $\beta$-barrel with an elliptical section and $3.2 \AA$ radius at the narrowest point through its path) was the scaffold of choice for inserting an amyloidogenic sequence due to its high copy number (ca. 20,000 molecules per cell), clustered as trimers in the membrane plane, which assures high density and valence of potential binding sites; ${ }^{26}$ its non-essentiality, due to its partial functional redundancy with other related porins, such as $\mathrm{OmpC}$, that allows for obtaining null strains; ${ }^{59}$ and its known three-dimensional structure which, combined with numerous biophysical studies, has unveiled its function as an electroselective import channel. ${ }^{27,29}$

To avoid any interference between the host native porin and the engineered $\mathrm{OmpF}$ variants, we first built a $\Delta o m p F$ null mutant in the E. coli MDS42 chassis. ${ }^{60}$ This is a derivative of the common MG1655 K-12 strain, with a reduced genome streamlined by the deletion of any chunk with origin in a mobile genetic element and with a relatively "naked" cell surface due to the lack of flagellum, pili, and fimbriae and the genes of a bunch of membrane proteins, that is, 18 (22\%) of the OMPs present in its parental strain, ${ }^{25}$ but still encoding for $o m p F$. Thus, the porin gene was deleted in MDS42 by replacement with a linear kanamycin-resistance cassette including genomic sequences flanking ompF (Figure S1a), using $\lambda$ Red recombination (Figure S1b). Gene replacement in the resulting MDS42 $\Delta o m p F$ strain was then confirmed by PCR (Figure S1c).

For the engineering of the external loops in $\mathrm{OmpF}$, the $o m p F$ gene was first synthesized in vitro, including a hexahistidine tag between the $\mathrm{N}$-terminal signal sequence, which is cleaved during Sec-dependent export through the inner membrane, ${ }^{38}$ and the start of the sequence coding for the matured OmpF (Figure S2). This gene was cloned into a plasmid vector including the low-copy number replicon RK2, an IPTG-inducible Ptac promoter, and its repressor $\left.(\operatorname{lacI})^{q}\right)^{61}$ thus becoming decoupled from the natural regulation of $o m p F$ expression, through $\mathrm{OmpR}$ and $\mathrm{MicF}$, in response to variations in the environmental osmotic conditions. ${ }^{62}$ This parental $o m p F$ construct was used as the platform to explore the insertion of a DNA sequence encoding the amyloidogenic hydrophobic stretch from the model bacterial prion-like protein RepA$\mathrm{WH} 1,{ }^{63,64}$ into the sequences coding for the eight extracellular loops in the $\beta$-barrel porin. In our design, the first and the last (the eighth) of the extracellular loops in OmpF were discarded 
a

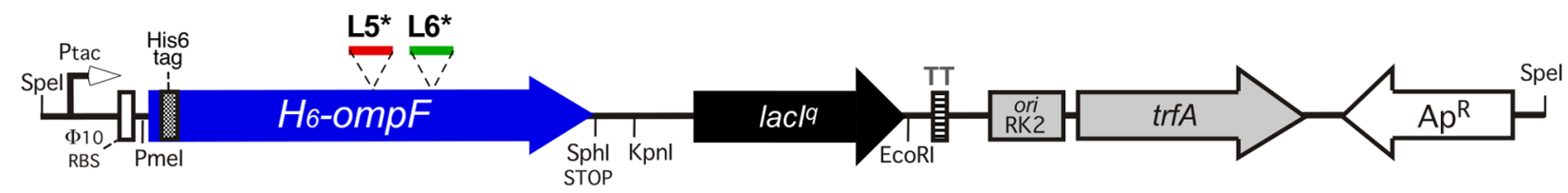

\section{pRK2-H6-OmpF-L5/L6}
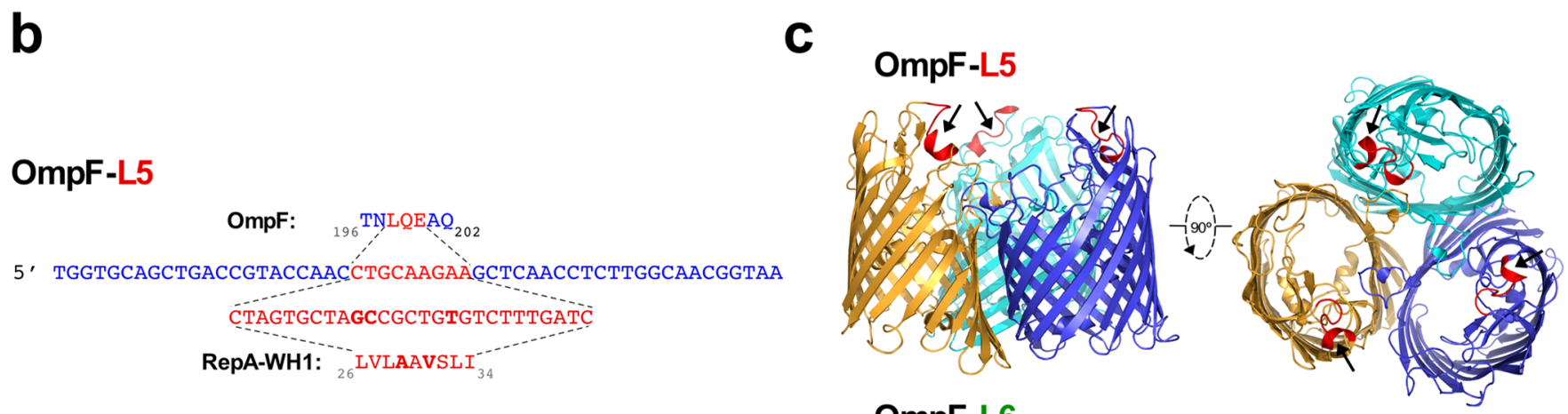

\section{OmpF-L6}

\section{OmpF-L6}

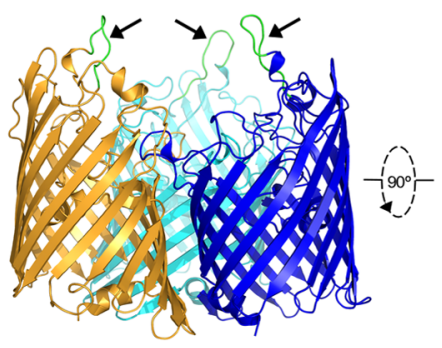

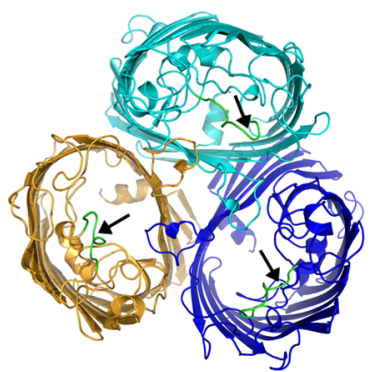

Figure 1. Generation and expression of external loop mutants (L5, red; L6, green) of the E. coli porin OmpF. (a) Scheme of the plasmid vector used for the expression of $\mathrm{His}_{6}$-tagged $o m p F$ alleles (blue), including an IPTG-inducible Ptac promoter, its lacI ${ }^{q}$ repressor (black), a transcription terminator (TT), and the broad host-range low-copy number RK2 replicon (gray). (b) Sequences of the coding strand oligonucleotides used for $o m p F$ mutagenesis, showing in red (L5) and green (L6) the DNA segments mutated to replace three wild-type amino acid residues in either of these loops (top line) by an insertion of a nine-residue amyloidogenic stretch from the prion-like protein RepA-WH1 (bottom line). (c) Two orthogonal views (left, sideward to the OM plane; right, normal to the OM) of the best score models generated by the Robetta server, ${ }^{82}$ for the two-mutant (L5 and L6) OmpF $\beta$-barrel trimers. Arrows point to the inserted amyloidogenic stretches.

because such hydrophobic insertion could interfere with the correct BAM-mediated assembly of the porin, which involves first the binding to the C-terminal strand and last the closure of the barrel by its antiparallel antiparallel bonding with the $\mathrm{N}$ terminal strand. ${ }^{39}$ The second loop was dismissed because it bridges contiguous subunits for the assembly of the porin as functional trimers. ${ }^{29}$ The third loop was not altered because it bends inward the porin barrel, to constrain the transit of ligands across the channel, while the fourth was untouched since it contributes to hold the bent conformation of L3. ${ }^{29}$ Finally, the seventh loop was not modified either because it has the shortest extension (just a three-residue tight turn). Thus, the fifth (L5) and sixth (L6) loops were chosen to be independently mutated by removing their three central (mainly polar) residues and substituting them by a nine-amino acid insertion (hydrophobic and amyloidogenic) from RepA-WH1 $\left({ }_{26}\right.$ LVLAAVSLI $\left._{34}\right)$ (Figure $1 \mathrm{~b}$ ). This stretch had been extensively characterized as a "chameleon" sequence, that is, a native $\alpha$-helical segment keen to adopt a $\beta$-strand conformation upon self-assembling as an amyloid, either when isolated or within the full-length protein ${ }^{63,65-67}$ or if artificially arranged in tandem repeats. ${ }^{6,69}$ The wild-type
Cys29 residue was mutated to Ala because, while it is not expected to alter the aggregation propensity of the sequence, it should avoid the possible oxidation of the native residue to cystine once exposed to extracellular medium, which is known to interfere with, for example, amyloid assembly of CsgA. ${ }^{70}$ To check that the engineered loops including the grafted amyloidogenic stretch would be exposed and accessible, the structures of the mutant porins were modeled on those of the wild-type OmpF (Figure 1c).

The expression of the porins (Figure 2a) with their L5 or L6 loops grafted with the amyloidogenic sequence and of the parental $\mathrm{OmpF}$ was first assessed through biochemical fractionation. This included the analysis of the cytosolic proteins present in the soluble cell lysate, the membrane proteins solubilized upon extraction of cell remnants with detergents (Triton X-100 and SB12), and the final insoluble materials, including both the $\mathrm{OM}$ and intracellular aggregates (Figure 2b). OmpF was identified, by western blotting with an anti-His tag antibody, as distributed between the detergentsoluble and -insoluble fractions. The antibody also highlighted the integrity of the distinct $\mathrm{OmpF}$ variants, with minor proteolytic degradation apparent as bands with higher 
a

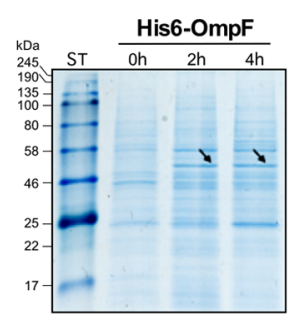

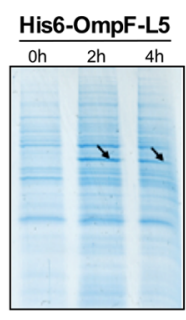

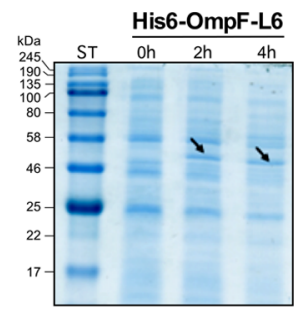

\section{b}
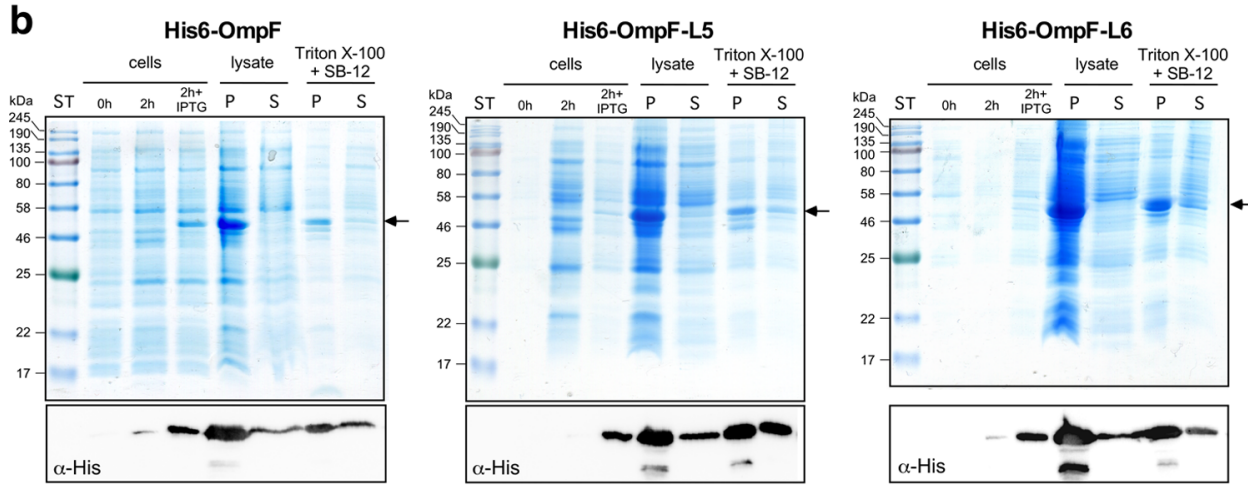

C
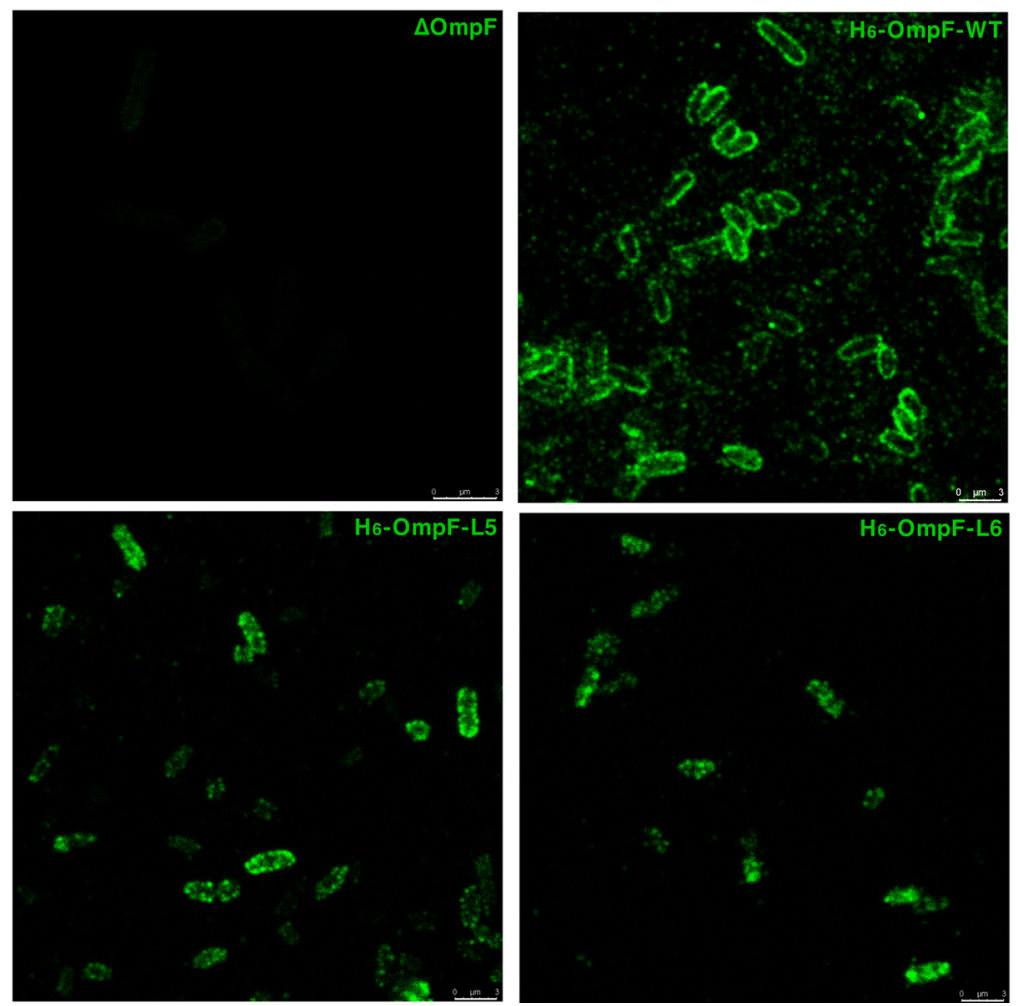

Figure 2. Engineered variants of $\mathrm{OmpF}$ are expressed in the $\mathrm{OM}$ of an $E$. coli $\Delta o m p F$ strain. (a) SDS-PAGE time course analysis of whole bacterial cells expressing $\mathrm{H}_{6}$-tagged $\mathrm{OmpF}$ porin (arrows), either the WT or variants with the amyloidogenic stretch inserted in the external loops L5 or L6. (b) Biochemical fractionation of the expressed OmpF variants (arrows). SDS-PAGE (top panel) displayed above the western blots of the same samples incubated with anti-His tag antibodies. The fraction soluble with non-ionic (Triton X-100) and zwitterionic (SB12) mild detergents probably corresponds to the porins as inserted in the OM. (c) Confocal microscopy sections of $E$. coli cells induced for $2 \mathrm{~h}$ and incubated with primary anti-His tag and secondary Alexa-488 antibodies (green). OmpF is located at the bacterial envelope, with a homogenous, clustered distribution for the WT and the L5 mutant, while forming polydispersed aggregates for L6.

electrophoretic mobility. The porin fraction that appears proteolyzed, evident even for OmpF-WT although it is more conspicuous for OmpF-L5 and especially for OmpF-L6, would correspond to protein molecules oversaturating the BAM machinery plus aggregates not competent for insertion at the
$\mathrm{OM}$, thus tagged for degradation. Immunofluorescence confocal microscopy of the cells, permeabilized to make accessible to the antibody the His-tag placed toward the periplasm, located both the OmpF-WT control and most of the OmpF-L5 as clusters distributed along the bacterial 
a
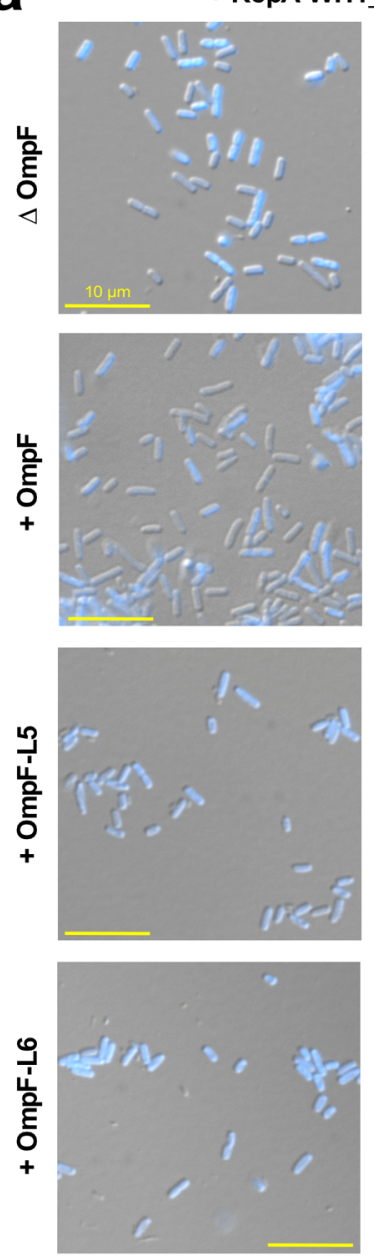

b

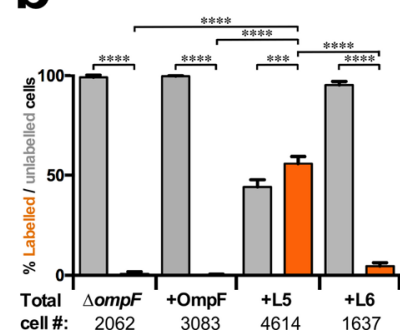

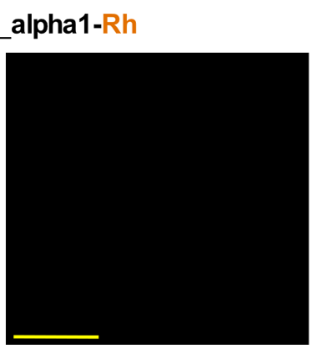
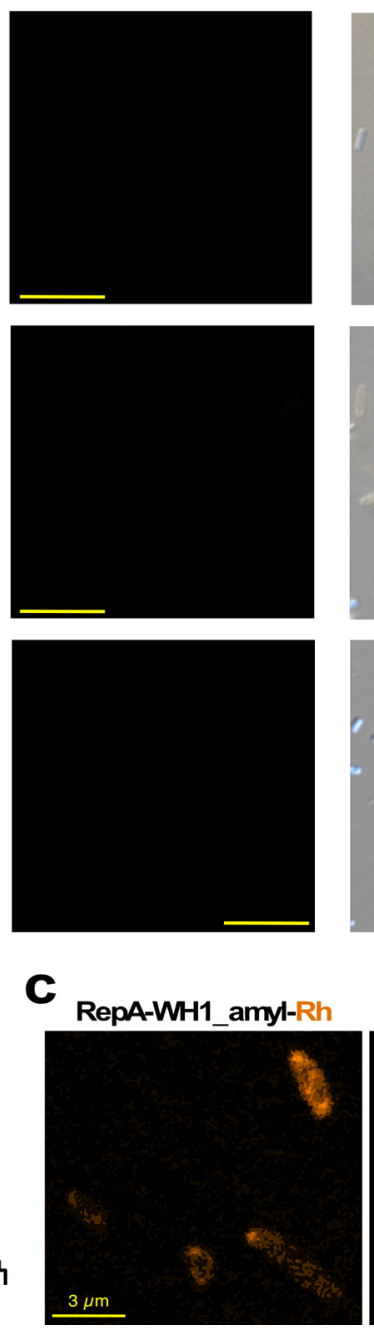

+ RepA-WH1_amyl-Rh
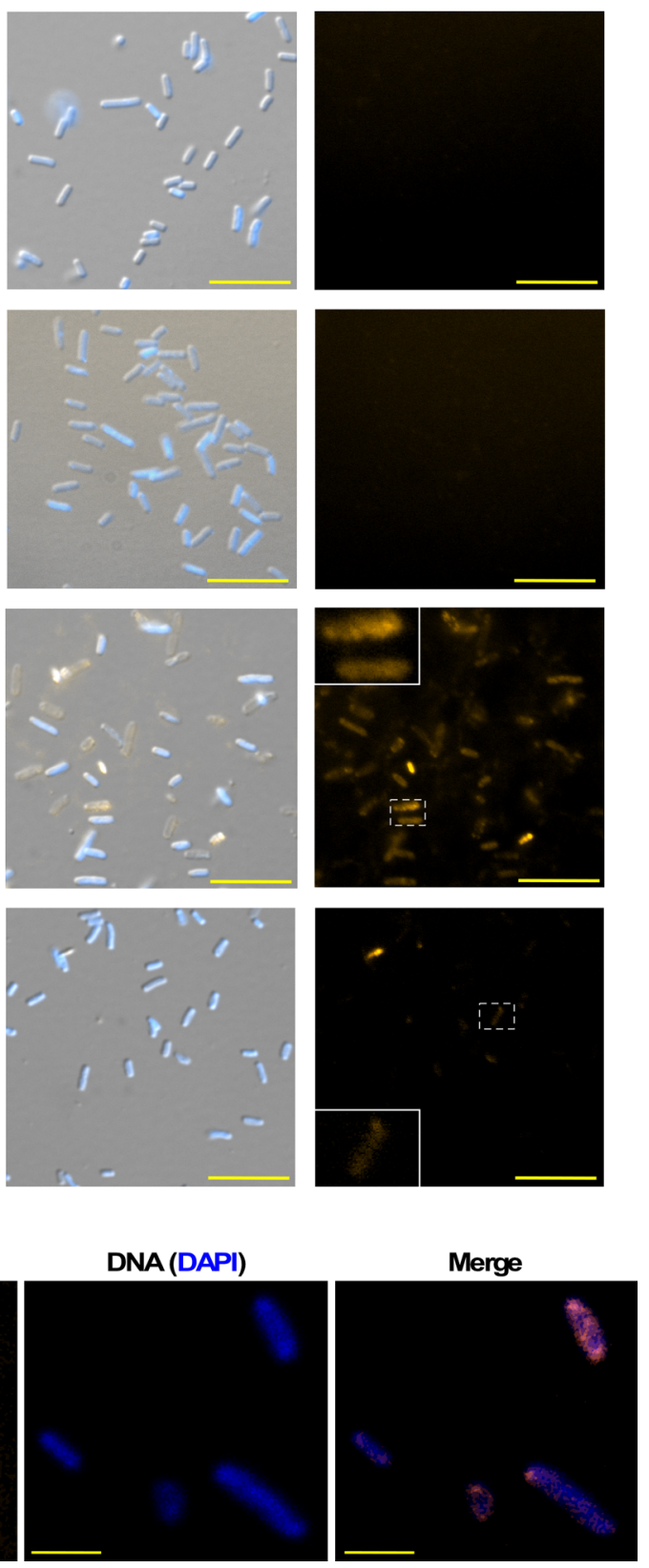

Figure 3. Targeting OmpF at the E. coli OM with an amyloidogenic peptide. (a) Epifluorescence microscopy reveals that the amyloidogenic stretch in the prion-like protein RepA-WH1, terminally labeled with rhodamine (amyl_Rh peptide, $1.4 \mu \mathrm{M}$ ) (Figure S5a), marks (orange) bacterial cells that express the porin with the same sequence grafted within an external loop (+OmpF-L5) but not control bacteria in which no porin was expressed $(\Delta \mathrm{OmpF})$ or those exposed the wild-type porin $(+\mathrm{OmpF})$ and, to a less extent, cells expressing the porin with a different engineered external loop (+OmpF-L6). A helical-prone soluble peptide from a different region in the same protein (alpha1_Rh, 1.4 $\mu \mathrm{M}$; Figure S5a) does not bind to any of the recombinant bacteria. Left-hand panels are superpositions of DIC and DAPI staining and rhodamine emission; right-hand panels show the isolated rhodamine (TRITC) channel. White frames are zoomed-in (3X) views. (b) Quantitative analysis of the bacterial cells targeted by the amyl_Rh peptide in (a). Bars show the average percentile values (orange, labeled cells; gray, unlabeled), and whiskers show the standard deviations, from three independent experiments. The total number of cells of each type counted is indicated. One-way ANOVA was performed, including Tukey's test for multiple comparisons within a $95 \%$ confidence interval: ****, $p<0.0001 ; * * *, p<0.001$. Statistical analysis was done with GraphPad Prism v.6. (c) Confocal microscopy section of OmpF-L5 cells titrated with the amyl_Rh peptide. The DAPI (DNA, blue) and rhodamine (bound peptide, orange) channels are shown together with their superposition.

envelope, while OmpF-L6 exhibited a more heterogeneous distribution with most of the signal found as cytosolic aggregates (Figure 2c). These results are compatible with the insertion of OmpF-WT and OmpF-L5 into the OM.

Grafting of amyloid stretches in porins can interfere with their correct insertion in the $\mathrm{OM}$, that is, by promoting cytoplasmic aggregation as shown here for a fraction of the OmpF-L6 mutant, with the likely outcome of triggering a protective response against envelope stress. ${ }^{71}$ A recent study on the BamA-promoted insertion of BamA itself illustrates that deletion of each of its eight extracellular loops can lead to the stall of porin folding, enhancing BamA differential suscepti- 

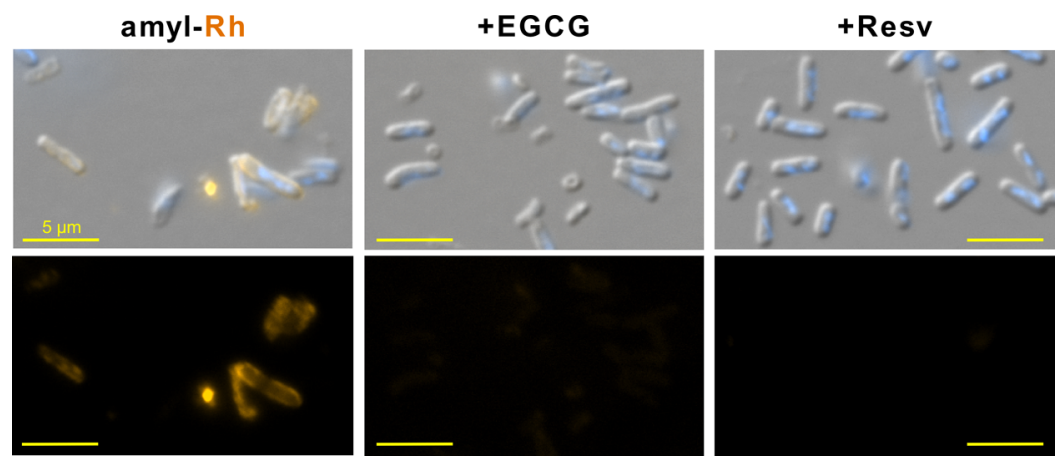

Figure 4. Natural polyphenols counteract the porin-peptide interaction. Epigallocatechin-3-gallate (EGCG) and resveratrol (Resv) competed with the binding of an amyloidogenic peptide to bacteria expressing at their $\mathrm{OM}$ a porin with the same amyloid-prone sequence grafted into an extracellular loop (OmpF-L5). Top row, superposition of DIC, DAPI, and TRICT images; bottom row, the TRICT (rhodamine) channel.

bility to the periplasmic protease DegP, with increasing sensitivity to proteolysis from L4 to $\mathrm{L} 8^{38}$ Nevertheless, as illustrated here with OmpF-L5, a majority of which managed to be inserted at the OM (Figure 2b,c), grafting a foreign amyloidogenic sequence into a loop can be compatible with the export of functional porins to the OM. In this sense, the expression of the distinct $\mathrm{OmpF}$ variants in bacteria cultured in microwell plates did not result in large differences in the stationary-phase cell growth densities achieved in LB medium when compared with the parental MDS42 and $\Delta o m p F$ strains. Although the expression of either the OmpF-WT allele or the amyloidogenic insertions, especially L5, did result in some delay in achieving the exponential phase, this did not substantially alter the bacterial growth rates (Figure S3), endorsing them as functional porins.

As observed for the $P$. stuartii porins Omp-Pst1/2, ${ }^{57}$ an indication for the exposure of loops with amyloidogenic potential is the tendency of bacterial cells to aggregate as clumps. Indeed, this was the case for E. coli grown on glass slides upon expression of OmpF-L5, to a larger extent than for those bacteria expressing OmpF-L6, the WT porin, or the noncomplemented parental null strain: their distinct ability to form biofilms, as evaluated through crystal violet staining (Figure $\mathrm{S} 4 \mathrm{a}$ ), and cell aggregates visible under the microscope (Figure S4b), both correlated with the expression of OmpF-L5. Although these studies did not allow us to unambiguously determine that the engineered OmpF-WT and OmpF-L5 were correctly inserted at the OM, this was further assessed by testing the ability of these cells and thus of the engineered porin extracellular loops to bind a homotypic amyloid peptide target.

Binding of an Amyloidogenic Peptide to the Outer Membrane is Dependent on Having the Same Sequence Grafted into the L5 Loop in OmpF. The extracellular accessibility of the loop-grafted $\mathrm{OmpF}$ porins and their ability to bind to the homotypic amyloidogenic sequence were challenged by incubation with two different peptides. The first one (RepA-WH1_alpha1) was a control comprising a segment close to the RepA N-terminus that, according to recent NMR studies, ${ }^{67}$ is highly soluble and $\alpha$-helical albeit with a dynamic propensity to unfold, whereas the second peptide (RepA-WH1 amyl) includes the same amyloidogenic stretch grafted into the OmpF loops ${ }^{63}$ but also its two natural flanking charged residues within RepA (Figure S5a). Both peptides were designed with the same number of amino acid residues (17), including acetylated and amidated $\mathrm{N}$ - and $\mathrm{C}$ termini, respectively, to mimic an internal protein chain context, and also an initial Tyr (for quantitation by UV light absorption) plus a $\mathrm{Gly}_{2}$ linker and a final $\mathrm{Gly}_{2}$-Lys tail. The $\varepsilon$ $\mathrm{NH} 2$ group in the C-terminal Lys is the only free amino group in both peptides and thus was used for the covalent attachment of a fluorescent rhodamine probe through N-hydroxysuccinimidyl (NHS) ester chemistry. Upon purification (Figure S5b) and mass spectrometry characterization (Figure S5c) of the fluorescent-labeled peptides, these were probed by incubation with bacterial cells expressing (or not) the distinct OmpF porin variants (Figure 3).

Epifluorescence microscopy revealed that the rhodaminetagged amyloidogenic peptide efficiently labeled bacteria expressing the porin with the same homotypic sequence grafted into its fifth extracellular loop (OmpF-L5; 56\% of the cells, when titrated with $1.4 \mu \mathrm{M}$ probe, but down to $0.25 \mu \mathrm{M}$ was tested as positive in binding) and to a much lesser extent (5\%) those cells expressing OmpF-L6 (Figure 3a,b). However, nearly no signal from this peptide was detected in the absence of complementation with the engineered porins $(\Delta \mathrm{OmpF})$ or when complemented through the expression of OmpF-WT (Figure 3a,b). Under the same incubation conditions, the control non-amyloidogenic peptide did not label any cell (Figure 3a). Confocal microscopy confirmed that the amyloidogenic peptide decorated the surface of bacteria that expressed OmpF-L5, with a preference for the cell poles (Figure 3c). Regarding the binding affinities of the engineered bacterial cells for the labeled amyloidogenic peptide, albeit the number of molecules of $\mathrm{OmpF}$ per cell is difficult to assess, yet considering a bacterium as the modular functional unit, achieving ca. $50 \%$ of cell binding with about $1 \mu \mathrm{M}$ peptide probe provides a first, rough glimpse for the affinity of their interaction. A rigorous appraisal of the binding affinity of the OmpF-L5 to the amyloidogenic peptide will require assays in which the porin trimers were reconstituted in model membranes with a defined stoichiometry.

To get insights into the biochemical nature of the interaction between the amyloidogenic stretches in OmpF-L5 and the probe RepA-WH1_amyl, binding of this peptide was competed with epigallocatechin-3-gallate (EGCG) or resveratrol, two natural polyphenolic molecules known to inhibit amyloid aggregation, and at the same concentration that was reported to interfere with RepA-WH1 amyloidogenesis both in vitro ${ }^{66}$ and in vivo. ${ }^{69}$ Epifluorescence microscopy revealed that the polyphenols efficiently abolished labeling of the bacterial cells by the fluorescent peptide (Figure 4), providing a strong indication for the amyloid nature of the homotypic interaction between the grafted loop in $\mathrm{OmpF}$ and its targeted sequence. 
a

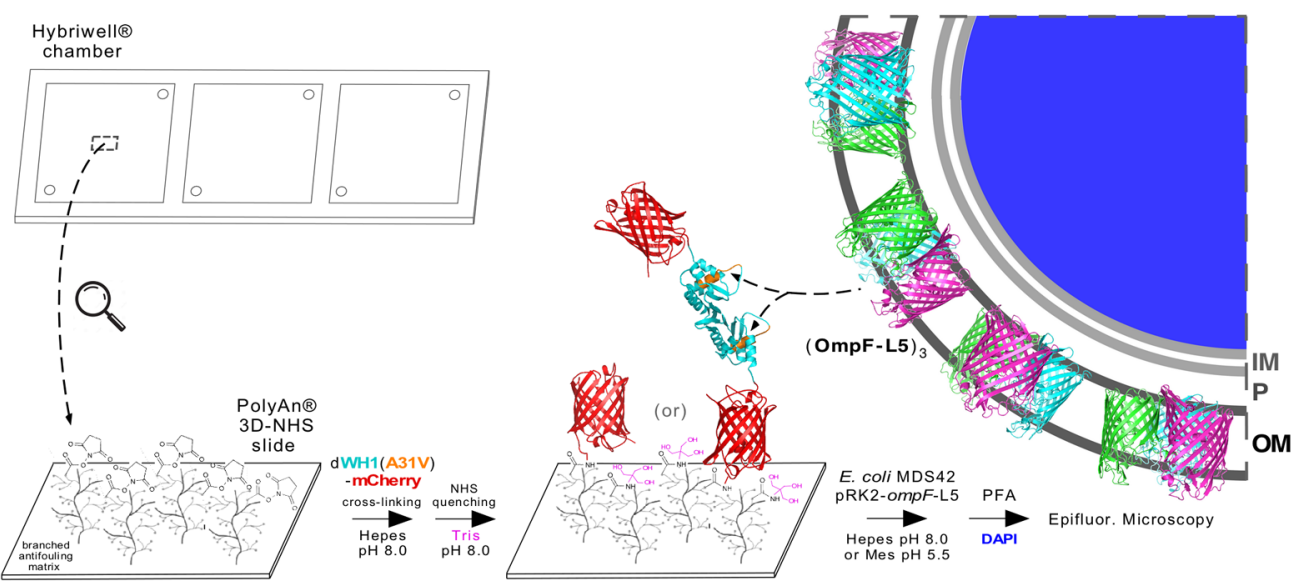

\section{b}
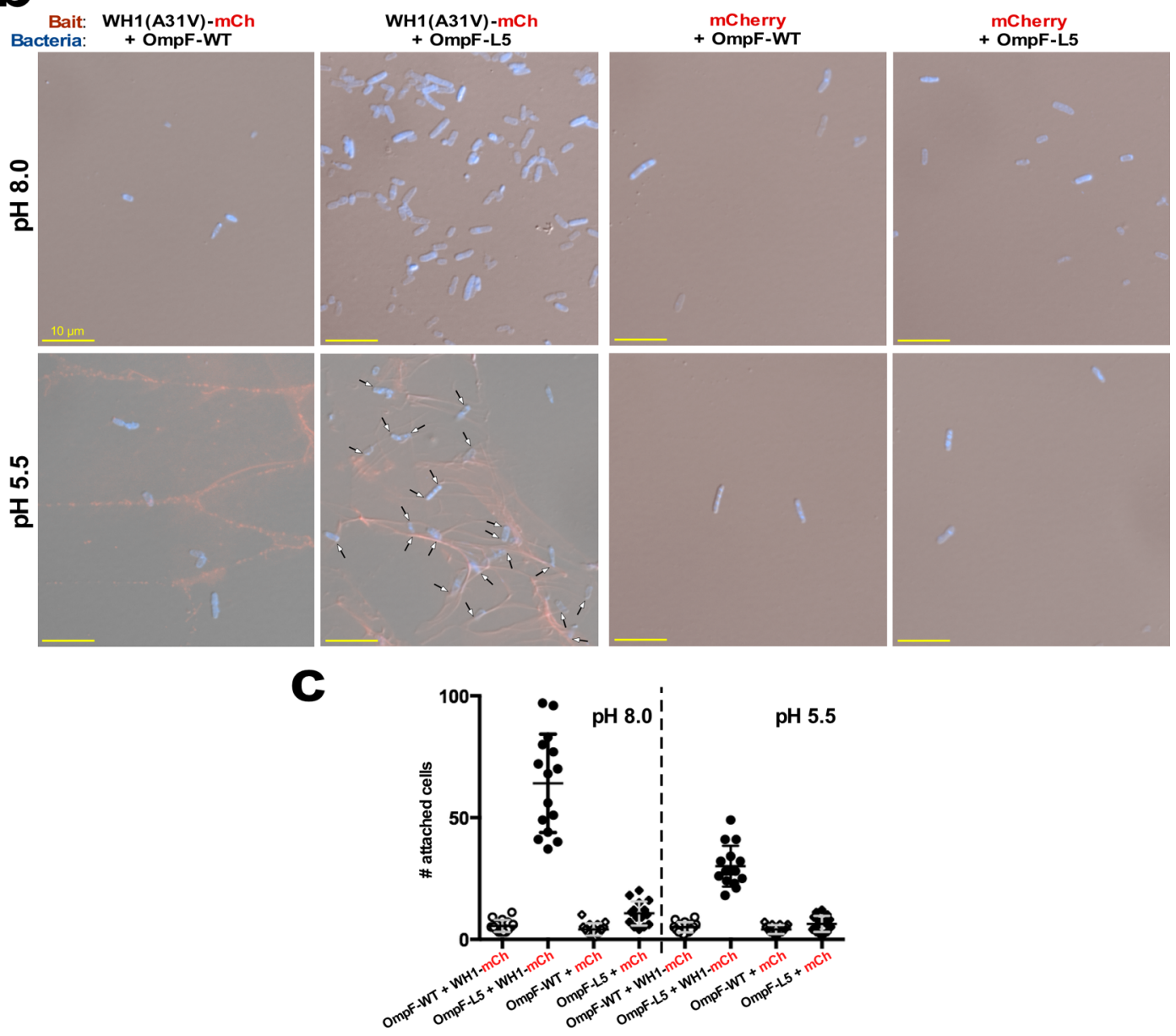

Figure 5. Monitoring the adhesion of E. coli cells displaying the engineered OmpF porin to surfaces functionalized with a prion-like protein including a homotypic amyloidogenic stretch. (a) Schematic overview of the experimental setting (not drawn to scale). Incubation chambers were casted on NHS-activated slides, coated with an anti-fouling matrix to reduce unspecific attachment of bacteria. NHS chemistry enabled the covalent immobilization of dimers RepA-WH1(A31V)-mCherry (cyan-red), which includes the same amyloidogenic sequence (orange) grafted in OmpFL5 or mCherry (red) as a control. Just two molecule orientations among the various possible ones are depicted. Upon quenching the excess of unreacted NHS groups with Tris (pink), cells were inoculated at the chambers in buffers of either acidic or basic pH and then extensively washed with the same buffer solutions. Bacteria were labeled with DAPI (blue) during fixation with PFA before observation. (b) Epifluorescence microscopy of the slides sketched in (a) after incubation either with bacteria displaying OmpF-WT or the grafted OmpF-L5. Bacteria expressing OmpF-L5, but not those bearing OmpF-WT, preferentially attached to the slides homogeneously coated with RepA-WH1(A31V)-mCherry (at pH 8.0) and, through a cell pole (arrows), to surfaces in which the amyloidogenic protein assembled as fibers (at $\mathrm{pH} 5.5$ ), rather than to the slides which displayed mCherry at either of the two pHs. (c) Quantitation of the bacteria attached in 15 distinct representative fields $(80.6 \times 61.4 \mu \mathrm{m}$ each) from two independent repeats of the experiment. One-way ANOVA analysis, with Tukey's test for multiple comparisons within a 95\% confidence interval, indicated that the differences observed for any pair of groups containing OmpF-L5 bound to WH1(A31V)-mCherry at both $\mathrm{pH}$ values are statistically significant with $p<0.0001$. Analysis performed with GraphPad Prism v.6. 
Bacteria Displaying the Grafted OmpF-L5 Target an Amyloidogenic Protein Immobilized on a Functionalized Surface. The ability of the engineered porin displayed on the bacterial OM to recognize the amyloidogenic sequence was also explored with the target attached to functionalized surfaces. Initial attempts were carried out with the RepAWH1_amyl peptide (Figure S5a) immobilized through disuccinimidyl glutarate cross-linking to poly-Lys-coated glass slides, but they failed due to a high background (unspecific) deposition of bacteria whatsoever the porin variant expressed. A second round was performed with the peptide linked to glass slides coated with an anti-fouling, ${ }^{72}$ low cell adhesion polymer functionalized with NHS groups, but nearly no bacteria attached, probably due to poor accessibility of the peptide within the matrix to the extracellular loops in the porin. Thus, a third strategy was successfully tested on the same NHSactivated slides (Figure 5a), but relying on the immobilization of RepA-WH1(A31V)-mCherry, the protein including the amyloidogenic peptide fused to a red fluorescent construct, extensively characterized on its ability to assemble cytotoxic intracellular, prion-like amyloid aggregates. ${ }^{61,65,73,74}$ For this otherwise soluble protein, amyloidogenesis is triggered by the binding of a number of ligands, ${ }^{64}$ while recent evidence shows that at acidic $\mathrm{pH}$, the conformational flexibility of both the $\alpha 1$ and $\alpha 5$ helices and the amyloidogenic loop is enhanced, ${ }^{67}$ which might promote aggregation by decreasing the stability of the fold. As a control, the isolated mCherry tag was similarly fixed to the same kind of the surface. Incubations of the protein-functionalized slides with bacteria expressing either OmpF-L5 or the control OmpF-WT were carried out (Figure 5a), either under the same conditions that resulted in binding of the amyloidogenic RepA-WH1 amyl peptide to the bacterial envelope ( $\mathrm{pH}$ 8.0; Figure 3) or at $\mathrm{pH}$ 5.5.

Under both buffer conditions, stable deposition of bacteria on the protein-coated surface was only appreciated for those cells expressing OmpF-L5 and when the protein targeted was RepA-WH1(A31V)-mCherry, with higher numbers of cells at $\mathrm{pH} 8.0$ (Figure 5b,c). Interestingly, while red fluorescence was homogenously distributed on the surface for RepA-WH1(A31V)-mCherry at the basic $\mathrm{pH}$, under the acidic conditions, it formed fibers that were decorated with bound bacteria. Albeit the orientation of bacteria on a homogeneous surface cannot be unambiguously determined from a projection, on the fibers, most bacteria attached through their cell poles. The dynamics of porin incorporation to the OM implies insertion in the mid-cell zone followed by the passive diffusion to the cell poles, where they form clusters of around $0.5 \mu \mathrm{m}$ diameter, ${ }^{75,76}$ resembling those visualized at the envelope for the engineered OmpF-L5. The observed polar attachment to an immobilized target protein by the bacterial cell rods expressing this porin is compatible with such a scenario. On the contrary, on surfaces functionalized with the control mCherry protein, the coating was homogeneous (so no fibers were assembled) at any $\mathrm{pH}$ of incubation, and cell deposition was much reduced, disregarding whether bacteria expressed the OmpF-L5 or WT (Figure 5b,c).

L4 and L5 loops in OmpF are those exhibiting the highest sequence variability, for example, in other Gram-negative bacteria such as Yersinia spp., ${ }^{77}$ suggesting that they might be adapted to distinct ecological interactors, including bacteriophages. ${ }^{32}$ However, such sequence evolvability also indicates that porin loops are subjected to selective pressure, which raises a note of caution on the likeliness of the appearance of suppressor mutations, either in the loops or elsewhere, if binding to the amyloidogenic sequences would come at a cost to the fitness of the engineered bacteria.

The amyloidogenic stretch grafted into OmpF, in its natural context within the plasmid replication protein RepA, contributes to the formation by its WH1 domain of a functional amyloid bridge that zips up together plasmid molecules for inhibiting untimely replication firing. ${ }^{78}$ However, in the isolated RepA-WH1 domain and upon conformational selection of an oligomeric species, the amyloidogenic stretch becomes a major determinant of cytotoxicity. ${ }^{61,65,73,74}$ As a tandemly repeated engineered peptide module, the same sequence elicits the aggregation of chimeric translation termination factors, both in yeast and in bacteria, enabling synthetic stop codon read-through translation. ${ }^{68,69}$ By insertion within the OmpF loop L5, this versatile modular sequence has been now repurposed for yet another function, tagging bacterial cells for molecular self-recognition of amyloids, which poses advantages over the usage of deliverable proteins as biosensors of prions and eventually for their bioremediation. Either with origin in human microbiota or in natural environments, protein amyloids constitute a threat for human and animal health due to their ability to cross-seed amyloid diseases. Biosensing the presence of such amyloidogenic proteins is necessarily the first step toward their clearance. The general validation of the bacterial device presented here will need inserting amyloidogenic stretches from other prion-like proteins, in particular those present in natural environments, into the porin loops.

\section{EXPERIMENTAL SECTION}

Genomic Deletion of ompF. On the reduced genome $E$. coli strain MDS42, ${ }^{60}$ deletion of the $o m p F$ gene was carried out through $\lambda$ Red recombination. Bacteria were first transformed with the pKD46 plasmid (pSC101 replicon-rep ${ }^{\text {ts }}, \mathrm{Ap}^{\mathrm{R}}, P_{\text {tet }} I-$ Sce, $P_{\text {araBAD }} \lambda$ red/exo-bet-gam, and araC), ${ }^{79}$ at $30{ }^{\circ} \mathrm{C}$. Then, competent cells previously grown for $1 \mathrm{~h}$ in the presence of $0.15 \%$ arabinose for $\lambda$ Red induction were electroporated with a linear PCR fragment including the $\mathrm{Km}^{\mathrm{R}}$ aphII gene from pWRG717, ${ }^{80}$ amplified with oligonucleotides including tails complementary to the genomic sequences flanking the $o m p F$ ORF (Figure S1a). Transformants were plated on LB agar supplemented with $50 \mu \mathrm{g} \cdot \mathrm{mL}^{-1}$ kanamycin and incubated at $37{ }^{\circ} \mathrm{C}$ for promoting the loss of pKD46. Positive clones replacing $o m p F$ with the $\mathrm{Km}^{\mathrm{R}}$ cassette (Figure $\mathrm{S} 1 \mathrm{~b}$ ) were identified by colony PCR (Figure S1c).

Construction of Loop-Engineered OmpF Variants. For complementation of MDS42 $\triangle o m p F$, a synthetic cassette (Figure S2) comprising a Ptac promoter, a translation initiation sequence (RBS), and ompF (WT) with its encoded signal sequence followed by a hexahistidine tag was generated by ATG/biosynthetics GmbH (https://www.atg-biosynthetics. com). This cassette was then cloned into the low-copy number vector $\mathrm{pRK} 2-W H 1-m$ Cherry $_{\text {lacI }}{ }^{q}{ }^{61}$ in which the PtacWH1-mCherry SpeI-SphI fragment was replaced with the equivalent synthetic Ptac-ompF (Figure 1a). As a matter of fact, successful cloning required that the recipient bacterial cells carried pRIL-lacI, a helper plasmid providing extra levels of the $\mathrm{LacI}^{\mathrm{q}}$ repressor, ${ }^{65}$ that was then readily eliminated by retransforming the plasmid mix into naive MDS42 $\Delta o m p F$ cells and then selecting for clones $\mathrm{Ap}^{\mathrm{R}}$ and $\mathrm{Cm}^{\mathrm{S}}$.

Engineering the amyloidogenic stretch in RepA-WH1(A31V) into ompF loops L5 and L6 was carried out by Pfu 
DNApol PCR extension of complementary mutagenic oligonucleotides (Figure 1b) on the $\mathrm{pRK} 2-o m p F(W T) l_{a c I^{q}}$ plasmid template (see above) plus removal of the parental plasmid strands by DpnI digestion. The oligonucleotides included an NheI site (GCTAGC) within the region encoding the amyloidogenic graft to enable a first screening of the resulting clones by restriction analysis. Mutant constructs were checked by DNA sequencing (Macrogen; https://dna. macrogen.com).

OmpF Expression and Localization within Bacterial Cells. Expression of the OmpF variants was carried out in the MDS42 $\Delta o m p F$ strain from overnight inocula in LB medium, supplemented with $100 \mu \mathrm{g} \cdot \mathrm{mL}^{-1}$ ampicillin, at $30{ }^{\circ} \mathrm{C}$. When $\mathrm{OD}_{600 \mathrm{~nm}}$ reached 0.3 , IPTG was added to $0.1 \mathrm{mM}$ and grown for up to $4 \mathrm{~h}$. Cells were harvested, and total protein contents were analyzed by (sodium dodecyl sulfate-polyacrylamide gel electrophoresis) SDS-PAGE (12.5\% PA) plus western blotting using a mouse monoclonal antibody recognizing the $\mathrm{N}$ terminal His6-tag (1:20,000; Sigma) and a secondary HRPconjugated goat anti-mouse antibody (1:20,000; Sigma), as described. $^{81}$

The formation of bacterial cell aggregates on the expression of the distinct porin constructs was explored by displaying 300 $\mu \mathrm{L}$ aliquots of the induced (or not) bacterial cultures in LabTek (Nunc) 8-well borosilicate lid-covered chambers and then leaving them to grow resting for $24 \mathrm{~h}$ at $30{ }^{\circ} \mathrm{C}$. The culture supernatant was then carefully removed, rinsed twice with 200 $\mu \mathrm{L}$ of $\mathrm{PBS}$, and finally fixed, for $30 \mathrm{~min}$ at room temperature (RT), with $100 \mu \mathrm{L}$ of $2 \%$ paraformaldehyde (PFA) in PBS, supplemented with $1 \mu \mathrm{L}$ of $0.5 \mathrm{mg} \cdot \mathrm{mL}^{-1} 4^{\prime}$,6-diamidino-2phenylindole (DAPI; Merck) in $\mathrm{H}_{2} \mathrm{O}$. Finally, chambers were washed with $200 \mu \mathrm{L}$ of PBS, disassembled, and mounted (Fluoromount-G; SouthernBiotech) on glass slides before observation under the microscope. In parallel, five replicas of the chambers, after removing the culture medium, were stained with crystal violet $(0.1 \%$ in water, for $15 \mathrm{~min})$ for biofilm detection. The excess stain was then removed, wells were washed there times with $300 \mu \mathrm{L}$ of Milli-Q water by pipetting, and the remaining, well-attached crystal violet was left to dry before resuspending in $300 \mu \mathrm{L}$ of $30 \%$ acetic acid. The same procedure was carried out in wells that had contained just LB medium, to be subtracted as a background (see below). $20 \mu \mathrm{L}$ of the contents of each chamber was diluted in $180 \mu \mathrm{L}$ of $30 \%$ acetic acid and transferred to a clear flat-bottom Thermo (Nunc) 96-well plate for measurement of the absorption at 550 $\mathrm{nm}$ in a Tecan Infinite $\mathrm{M}$ Plex microplate reader.

Biochemical fractionation of bacteria was performed with cells induced for $2 \mathrm{~h}$ at $30{ }^{\circ} \mathrm{C}$ in $50 \mathrm{~mL}$ cultures (as shown above). Bacteria were harvested, washed with cold $0.9 \% \mathrm{NaCl}$, and resuspended in $1.0 \mathrm{M} \mathrm{KCl}, 60 \mathrm{mM}$ imidazole $\cdot \mathrm{HCl} \mathrm{pH} 8$, $1 \%$ Brij-58 (polyethyleneglycol hexadecyl ether; Sigma), $1 \mathrm{mM}$ p-aminobenzamidine, and $10 \%$ glycerol, before being lysed on ice by sonication $(2 \times 45 \mathrm{~s}$ at $20 \%$ intensity, Branson sonifier thin tip). The lysate was then centrifuged at $29,000 \times g$ (Fiberlite F13-14 rotor; Sorvall) for $30 \mathrm{~min}$ at $4{ }^{\circ} \mathrm{C}$. Pellets were resuspended in $0.1 \mathrm{M} \mathrm{KCl}, 50 \mathrm{mM}$ Tris $\cdot \mathrm{HCl} \mathrm{pH} \mathrm{7.2,} 2$ mM DTT, 1 mM EDTA, 1\% Triton X-100, 0.5\% SB12 (Ndodecyl-N,N-dimethylammonio-3-propane sulfonate; Serva), and $10 \%$ glycerol, and sonication was carried out as mentioned above, followed by centrifugation under the same conditions.

Targeting of the engineered porins to the OM was assessed by immunofluorescence microscopy. Upon porin expression (see above), cells from $1 \mathrm{~mL}$ cultures were harvested, washed with cold $0.9 \% \mathrm{NaCl}$, and incubated with $8 \mu \mathrm{g} \cdot \mathrm{mL}^{-1}$ lysozyme (Sigma) for $5 \mathrm{~min}$ at RT, to make the periplasm-oriented His6tag accessible to the antibodies. Cells were gently washed in cold PBS before labeling with a monoclonal anti-His antibody (1:500; Sigma) and then with an anti-mouse Alexa 488conjugated antibody (1:500; Thermo-Fisher), as described. ${ }^{81}$ Bacteria were then observed using confocal laser microscopy (see below).

Peptide Labeling and Solution Binding Assays to Engineered Bacterial Cells. Peptides RepA-WH1_amyl and RepA-WH1_alpha1 (Figure S5a) were synthesized (AAPPtec Focus XC; solid-phase Fmoc) at the Protein Chemistry Facility (CIB-CSIC). Six milligrams of each peptide was dissolved in $100 \mu \mathrm{L}$ of 1,1,1,3,3,3-hexafluoro-2-propanol (HFIP; Fluka) and incubated for $1 \mathrm{~h}$ at $40{ }^{\circ} \mathrm{C}$ and $1400 \mathrm{rpm}$ agitation in an Eppendorf Thermomixer, producing an aggregate-free solution. Peptides were then dried out at RT in a SpeedVac (Thermo) and then resuspended in dimethyl sulfoxide (DMSO; Merck) to a concentration of $4.5 \mathrm{mM}$ (as determined by $A_{280 \mathrm{~nm}}$ of the Tyr residue). For labeling the C-terminal Lys in the peptides with 5/6-carboxytetramethylrhodamine succinimidyl ester (NHS-rhodamine; Thermo), $500 \mu \mathrm{L}$ reaction aliquots were casted including $300 \mu \mathrm{M}$ peptide in $10 \% \mathrm{DMSO}$, $0.1 \mathrm{M}$ Hepes $\mathrm{pH} 8$, and $1.3 \mathrm{mM}$ NHS-rhodamine and left to react at $25^{\circ} \mathrm{C}$ with agitation $(300 \mathrm{rpm})$ for $16 \mathrm{~h}$ in the dark. While the alphal peptide remained mostly soluble, the amyl peptide precipitated and was harvested by centrifugation $(16,500 \times g, 5 \mathrm{~min})$. The amyl peptide was solubilized in $10 \%$ HFIP and $0.5 \%$ trifluoracetic acid (TFA), while the alpha1 was supplemented with these reagents. Labeled peptides were separated from the unreacted NHS-rhodamine by fast protein liquid chromatography in a $1 \mathrm{~mL}$ octyl-Sepharose hydrophobic interaction chromatography column (GE Healthcare) wrapped with aluminum foil, developing a $10 \mathrm{~mL}$ gradient between $0.1 \%$ TFA in $\mathrm{H}_{2} \mathrm{O}$ and $75 \%$ acetonitrile, $0.1 \%$ TFA, and $\mathrm{H}_{2} \mathrm{O}$ (Figure S5b). Peak fractions were evaporated (SpeedVac), resuspended in $100 \mu \mathrm{L}$ of DMSO, and stored at $-20{ }^{\circ} \mathrm{C}$. The concentration of the labeled peptides was calculated by measuring the $A_{552 \mathrm{~nm}}\left(\varepsilon_{552}=80,000 \mathrm{M}^{-1} \cdot \mathrm{cm}^{-1}\right)$. The mass of the peptide adducts was determined by MALDI-TOF/TOF mass spectrometry at the Proteomics Facility (CNB-CSIC) (Figure S5c).

For assessing peptide binding to bacteria, IPTG-induced (or un-induced) cells were harvested after $2 \mathrm{~h}$ at $30{ }^{\circ} \mathrm{C}$ (see above), washed twice with $1 \mathrm{~mL}$ of cold $15 \mathrm{mM} \mathrm{NaCl}$ and 20 $\mathrm{mM}$ Hepes $\mathrm{pH} 8$, and resuspended in the same buffer to $\mathrm{OD}_{600 \mathrm{~nm}}=1$. In $2 \mathrm{~mL}$ Eppendorf tubes, $200 \mu \mathrm{L}$ of the bacterial suspension (ca. $1.6 \times 10^{8}$ cells) was incubated with distinct concentrations $(0.25-11 \mu \mathrm{M})$ of the rhodaminelabeled peptides in $1 \mathrm{~mL}$ final volume of $15 \mathrm{mM} \mathrm{NaCl}, 20 \mathrm{mM}$ Hepes $\mathrm{pH} \mathrm{8}$, and 9\% DMSO. Binding of the amyloidogenic peptide to bacteria expressing OmpF-L5 was found to be sensitive to the salt concentration, standing up to $150 \mathrm{mM}$ $\mathrm{NaCl}$, while DMSO was required to keep the peptide in solution, being compatible with the interaction in the interval between 5 and $10 \%$. Incubation proceeded during $16 \mathrm{~h}$ at $4{ }^{\circ} \mathrm{C}$ in a rotating wheel. Then, bacteria were sedimented and washed twice by pipetting with $1 \mathrm{~mL}$ of cold $15 \mathrm{mM} \mathrm{NaCl}$ and $20 \mathrm{mM}$ Hepes $\mathrm{pH}$ 8. Samples were fixed with PFA supplemented with DAPI (see above), and $10 \mu \mathrm{L}$ drops of the final cell suspension were spread on glass slides and mounted for microscopy. To test polyphenol interference with the binding of the amyloidogenic peptide to the cell surface, 
EGCG or resveratrol was included at the incubation step at $250 \mu \mathrm{M}$ (from $25 \mathrm{mM}$ stocks in DMSO).

Bacterial Cell Binding to Immobilized Fluorescent Protein Targets. SecureSeal adhesive chambers (HybriWell) were mounted on 3D-NHS-functionalized slides (polyAn $\mathrm{GmbH})$ coated with an anti-fouling, low-cell adhesion matrix. The protein which the amyl peptide comes from, $\mathrm{His}_{6}$-RepAWH1 $(\mathrm{A} 31 \mathrm{~V})$-mCherry, and a $\mathrm{His}_{6}$-mCherry control were purified as reported ${ }^{66}$ and then placed with a thin tip in the chambers at a final concentration of $20 \mu \mathrm{M}$ in $100 \mu \mathrm{L}$ of 154 $\mathrm{mM} \mathrm{NaCl}, 50 \mathrm{mM}$ Hepes $\mathrm{pH}$, and $0.1 \mathrm{mM}$ EDTA. Protein immobilization proceeded at RT, with orbital shaking (100 $\mathrm{rpm}$ ) in the dark for $16 \mathrm{~h}$. The protein solution was then removed, and any remaining unreacted NHS groups were quenched with $1 \mathrm{M}$ Tris $\mathrm{pH} 8$ for $2 \mathrm{~h}$. Chambers were then washed twice for $30 \mathrm{~min}$ with $154 \mathrm{mM} \mathrm{NaCl}$ and $20 \mathrm{mM}$ Hepes pH 8 (or $20 \mathrm{mM}$ Mes pH 5.5). Bacterial cells, processed as indicated above for their incubation with the labeled peptides but in buffers either at $\mathrm{pH} 8.0$ or 5.5 and at an $\mathrm{OD}_{600 \mathrm{~nm}}$ of $0.1\left(100 \mu \mathrm{L}, \mathrm{ca} .8 \times 10^{6}\right.$ cells $)$, were then placed into the chambers and incubated in a fridge for $16 \mathrm{~h}$. Afterward, bacterial cell suspensions were drained, the adhesive incubation chambers were removed, and the slides were washed three times (for 20 min each at RT) with $4 \mathrm{~mL}$ of their corresponding $\mathrm{pH} 8.0$ or 5.5 buffer, before PFA fixation, DAPI staining, and mounting for microscopy (see above).

Microscopy. Epifluorescence microscopy was performed with a Nikon Eclipse 90i equipped with CFI PLAN APO VC $100 \times / 1.40 \mathrm{NA}$ and $60 \times / 1.40 \mathrm{NA}$ oil immersion objectives and a Hamamatsu ORCA-R ${ }^{2}$ CCD camera. For the indicated fluorophores, the filters (Semrock) were rhodamine (excitation: 543/22, emission: 593/40; 1 s exposure) and DAPI (ex: 360/40, em: 470/40; $0.4 \mathrm{~s}$ exp). Differential interference contrast (DIC) images were also captured.

Confocal laser microscopy was carried out in a multispectral Leica TCS SP8X, equipped with a HC PL APO CS2 100x/ 1.40 NA oil objective with 1.518 refraction index. The laser excitation line was set to $488 \mathrm{~nm}$ for the green fluorophore (Alexa 488-conjugated antibody; emission 522-552 nm, 122 $\mu \mathrm{m}$ pinhole), to $555 \mathrm{~nm}$ for the orange fluorophore (rhodamine-labeled peptides; em. 567-610 nm, $151 \mu \mathrm{m}$ pinhole), and $405 \mathrm{~nm}$ for the blue fluorophore (DAPI; em. $422-475 \mathrm{~nm}$ ). Confocal optical sections were set to $0.548 \mathrm{~nm}$.

\section{CONCLUSIONS}

In summary, this study shows that inserting an amyloid-prone sequence into the $\mathrm{OM}$ porin $\mathrm{OmpF}$ enables the bacteria to become attached to the same sequence, either as a free peptide or forming part of a prion-like protein. This illustrates the potential of homotypic interactions in amyloid assembly as a means to implement specific molecular recognition between bacteria and extracellular proteins. These results open a way to the bioremediation by bacteria of potentially harmful amyloids present in natural environments.

\section{ASSOCIATED CONTENT}

\section{SI Supporting Information}

The Supporting Information is available free of charge at https://pubs.acs.org/doi/10.1021/acssynbio.1c00347.

Construction of a $\Delta o m p F$ mutant for expression of engineered $\mathrm{OmpF}$ variants, sequence of the synthetic ompF gene, growth curves of bacteria expressing the distinct $\mathrm{OmpF}$, formation of biofilms and cellular aggregates by bacteria exposing the OmpF variants, and characterization of the rhodamine-labeled peptides (PDF)

\section{AUTHOR INFORMATION}

\section{Corresponding Author}

Rafael Giraldo - Department of Microbial Biotechnology, National Centre for Biotechnology (CSIC), 28049 Madrid, Spain; Department of Cellular and Molecular Biology, Centro de Investigaciones Biológicas (CSIC), 28040 Madrid, Spain; 이이.org/0000-0002-5358-7488; Email: rgiraldo@ cnb.csic.es

\section{Authors}

Sol Vendrell-Fernández - Department of Microbial Biotechnology, National Centre for Biotechnology (CSIC), 28049 Madrid, Spain; Present Address: Genetics of Biofilms Unit, Institut Pasteur, 75015 Paris, France

Paloma Lozano-Picazo - Department of Cellular and Molecular Biology, Centro de Investigaciones Biológicas (CSIC), 28040 Madrid, Spain; Present Address: Centre for Biomedical Technology, Technical University of Madrid, 28223 Pozuelo de Alarcón-Madrid, Spain.

Paula Cuadros-Sánchez - Department of Microbial Biotechnology, National Centre for Biotechnology (CSIC), 28049 Madrid, Spain; Present Address: Hospital Emiro Quintero Cañizares, 546551 Ocaña, Colombia.

María M. Tejero-Ojeda - Department of Cellular and Molecular Biology, Centro de Investigaciones Biológicas (CSIC), 28040 Madrid, Spain; Present Address: Dept. of Molecular Neurobiology, Cajal Institute (CSIC), 28002 Madrid, Spain.

Complete contact information is available at: https://pubs.acs.org/10.1021/acssynbio.1c00347

\section{Author Contributions}

S.V.-F. and P.L.-P contributed equally to this work. S.V.-F. carried out the work with peptides and on their binding to cells and analyzed data. P.L.-P. constructed the $\Delta o m p F$ bacterial strain and expression plasmids and developed, together with P.C.-S., the protocol for biochemical analysis of membranes. M.M.T.-O. built the L5 and L6 ompF mutants. R.G. conceived the project, performed experiments, analyzed data, and wrote the article with contributions from all the authors.

\section{Notes}

The authors declare no competing financial interest.

\section{ACKNOWLEDGMENTS}

We are indebted to Sylvia Gutiérrez-Erlandsson and Ana OñaBlanco (CNB-CSIC) for their help with confocal microscopy, to Javier Varela (CIB-CSIC) for peptide synthesis, to Sergio Ciordia (CNB-CSIC) for mass spectrometry of the peptides, and to Cristina Fernández for the mCherry-tagged proteins. This work has been financed with grant RTI2018-094549-BI00 from the Spanish MCIN/AEI (10.13039/501100011033 and FEDER "A way to make Europe") to R.G. P.L.-P. was a recipient of a EU Young Employment Initiative Grant (YEI 2015-CS_MAD_CIB_091). P.C.-S. was a recipient of a grant from Fundación Carōina 2018-2019. 


\section{REFERENCES}

(1) Eisenberg, D. S.; Sawaya, M. R. Structural studies of amyloid proteins at the molecular level. Annu. Rev. Biochem. 2017, 86, 69-95.

(2) Iadanza, M. G.; Jackson, M. P.; Hewitt, E. W.; Ranson, N. A.; Radford, S. E. A new era for understanding amyloid structures and disease. Nat. Rev. Mol. Cell Biol. 2018, 19, 755-773.

(3) Levkovich, S. A.; Gazit, E.; Laor Bar-Yosef, D. Two decades of studying functional amyloids in microorganisms. Trends Microbiol. 2021, 29, 251-265.

(4) Zabel, M.; Ortega, A. The ecology of prions. Microbiol. Mol. Biol. Rev. 2017, 81, e00001-17.

(5) Kuznetsova, A.; McKenzie, D.; Cullingham, C.; Aiken, J. M. Long-term incubation $\operatorname{Pr} \mathrm{P}(\mathrm{CWD})$ with soils affects prion recovery but not infectivity. Pathogens 2020, 9, 311.

(6) Chapman, M. R.; Robinson, L. S.; Pinkner, J. S.; Roth, R.; Heuser, J.; Hammar, M.; Normark, S.; Hultgren, S. J. Role of Escherichia coli curli operons in directing amyloid fiber formation. Science 2002, 295, 851-855.

(7) Van Gerven, N.; Van der Verren, S. E.; Reiter, D. M.; Remaut, $\mathrm{H}$. The role of functional amyloids in bacterial virulence. J. Mol. Biol. 2018, 430, 3657-3684.

(8) Lundmark, K.; Westermark, G. T.; Olsén, A.; Westermark, P. Protein fibrils in nature can enhance amyloid protein A amyloidosis in mice: Cross-seeding as a disease mechanism. Proc. Natl. Acad. Sci. U.S.A. 2005, 102, 6098-6102.

(9) Hartman, K.; Brender, J. R.; Monde, K.; Ono, A.; Evans, M. L.; Popovych, N.; Chapman, M. R.; Ramamoorthy, A. Bacterial curli protein promotes the conversion of PAP248-286 into the amyloid SEVI: cross-seeding of dissimilar amyloid sequences. PeerJ 2013, 1, No. e5.

(10) Chen, S. G.; Stribinskis, V.; Rane, M. J.; Demuth, D. R.; Gozal, E.; Roberts, A. M.; Jagadapillai, R.; Liu, R.; Choe, K.; Shivakumar, B.; Son, F.; Jin, S.; Kerber, R.; Adame, A.; Masliah, E.; Friedland, R. P. Exposure to the functional bacterial amyloid protein curli enhances alpha-synuclein aggregation in aged Fischer 344 rats and Caenorhabditis elegans. Sci. Rep. 2016, 6, 34477.

(11) Friedland, R. P.; Chapman, M. R. The role of microbial amyloid in neurodegeneration. PLoS Pathog. 2017, 13, No. e1006654.

(12) Sampson, T. R.; Challis, C.; Jain, N.; Moiseyenko, A.; Ladinsky, M. S.; Shastri, G. G.; Thron, T.; Needham, B. D.; Horvath, I.; Debelius, J. W.; Janssen, S.; Knight, R.; Wittung-Stafshede, P.; Gradinaru, V.; Chapman, M.; Mazmanian, S. K. A gut bacterial amyloid promotes $\alpha$-synuclein aggregation and motor impairment in mice. eLife 2020, 9, No. e53111.

(13) Blacher, E.; Bashiardes, S.; Shapiro, H.; Rothschild, D.; Mor, U.; Dori-Bachash, M.; Kleimeyer, C.; Moresi, C.; Harnik, Y.; Zur, M.; Zabari, M.; Brik, R. B.-Z.; Kviatcovsky, D.; Zmora, N.; Cohen, Y.; Bar, N.; Levi, I.; Amar, N.; Mehlman, T.; Brandis, A.; Biton, I.; Kuperman, Y.; Tsoory, M.; Alfahel, L.; Harmelin, A.; Schwartz, M.; Israelson, A.; Arike, L.; Johansson, M. E. V.; Hansson, G. C.; Gotkine, M.; Segal, E.; Elinav, E. Potential roles of gut microbiome and metabolites in modulating ALS in mice. Nature 2019, 572, 474-480.

(14) Sampson, T. R.; Debelius, J. W.; Thron, T.; Janssen, S.; Shastri, G. G.; Ilhan, Z. E.; Challis, C.; Schretter, C. E.; Rocha, S.; Gradinaru, V.; Chesselet, M.-F.; Keshavarzian, A.; Shannon, K. M.; KrajmalnikBrown, R.; Wittung-Stafshede, P.; Knight, R.; Mazmanian, S. K. Gut microbiota regulate motor deficits and neuroinflammation in a model of Parkinson's disease. Cell 2016, 167, 1469-1480.

(15) Morais, L. H.; Schreiber, H. L.; Mazmanian, S. K. The gut microbiota-brain axis in behaviour and brain disorders. Nat. Rev. Microbiol. 2021, 19, 241-255.

(16) Nejman, D.; Livyatan, I.; Fuks, G.; Gavert, N.; Zwang, Y.; Geller, L. T.; Rotter-Maskowitz, A.; Weiser, R.; Mallel, G.; Gigi, E.; Meltser, A.; Douglas, G. M.; Kamer, I.; Gopalakrishnan, V.; Dadosh, T.; Levin-Zaidman, S.; Avnet, S.; Atlan, T.; Cooper, Z. A.; Arora, R.; Cogdill, A. P.; Khan, M. A. W.; Ologun, G.; Bussi, Y.; Weinberger, A.; Lotan-Pompan, M.; Golani, O.; Perry, G.; Rokah, M.; Bahar-Shany, K.; Rozeman, E. A.; Blank, C. U.; Ronai, A.; Shaoul, R.; Amit, A.; Dorfman, T.; Kremer, R.; Cohen, Z. R.; Harnof, S.; Siegal, T.;
Yehuda-Shnaidman, E.; Gal-Yam, E. N.; Shapira, H.; Baldini, N.; Langille, M. G. I.; Ben-Nun, A.; Kaufman, B.; Nissan, A.; Golan, T.; Dadiani, M.; Levanon, K.; Bar, J.; Yust-Katz, S.; Barshack, I.; Peeper, D. S.; Raz, D. J.; Segal, E.; Wargo, J. A.; Sandbank, J.; Shental, N.; Straussman, R. The human tumor microbiome is composed of tumor type-specific intracellular bacteria. Science 2020, 368, 973-980.

(17) Bund, T.; Nikitina, E.; Chakraborty, D.; Ernst, C.; Gunst, K.; Boneva, B.; Tessmer, C.; Volk, N.; Brobeil, A.; Weber, A.; Heikenwalder, M.; Zur Hausen, H.; de Villiers, E.-M. Analysis of chronic inflammatory lesions of the colon for BMMF Rep antigen expression and CD68 macrophage interactions. Proc. Natl. Acad. Sci. U.S.A. 2021, 118, No. e2025830118.

(18) Nguyen, P. Q.; Botyanszki, Z.; Tay, P. K. R.; Joshi, N. S. Programmable biofilm-based materials from engineered curli nanofibres. Nat. Commun. 2014, 5, 4945.

(19) Nguyen, P. Q.; Courchesne, N.-M. D.; Duraj-Thatte, A.; Praveschotinunt, P.; Joshi, N. S. Engineered living materials: Prospects and challenges for using biological systems to direct the assembly of smart materials. Adv. Mater. 2018, 30, 1704847.

(20) Praveschotinunt, P.; Duraj-Thatte, A. M.; Gelfat, I.; Bahl, F.; Chou, D. B.; Joshi, N. S. Engineered E. coli Nissle 1917 for the delivery of matrix-tethered therapeutic domains to the gut. Nat. Commun. 2019, 10, 5580.

(21) Tay, P. K. R.; Nguyen, P. Q.; Joshi, N. S. A synthetic circuit for mercury bioremediation using self-assembling functional amyloids. ACS Synth. Biol. 2017, 6, 1841-1850.

(22) Piñero-Lambea, C.; Bodelón, G.; Fernández-Periáñez, R.; Cuesta, A. M.; Álvarez-Vallina, L.; Fernández, L. Á. Programming controlled adhesion of E. coli to target surfaces, cells, and tumors with synthetic adhesins. ACS Synth. Biol. 2015, 4, 463-473.

(23) Glass, D. S.; Riedel-Kruse, I. H. A synthetic bacterial cell-cell adhesion toolbox for programming multicellular morphologies and patterns. Cell 2018, 174, 649-658.

(24) De Genst, E.; Messer, A.; Dobson, C. M. Antibodies and protein misfolding: From structural research tools to therapeutic strategies. Biochim. Biophys. Acta 2014, 1844, 1907-1919.

(25) Horne, J. E.; Brockwell, D. J.; Radford, S. E. Role of the lipid bilayer in outer membrane protein folding in Gram-negative bacteria. J. Biol. Chem. 2020, 295, 10340-10367.

(26) Vergalli, J.; Bodrenko, I. V.; Masi, M.; Moynié, L.; AcostaGutiérrez, S.; Naismith, J. H.; Davin-Regli, A.; Ceccarelli, M.; van den Berg, B.; Winterhalter, M.; Pagès, J.-M. Porins and small-molecule translocation across the outer membrane of Gram-negative bacteria. Nat. Rev. Microbiol. 2020, 18, 164-176.

(27) Dhakshnamoorthy, B.; Raychaudhury, S.; Blachowicz, L.; Roux, B. Cation-selective pathway of $\mathrm{OmpF}$ porin revealed by anomalous $\mathrm{X}$ ray diffraction. J. Mol. Biol. 2010, 396, 293-300.

(28) Wang, J.; Bafna, J. A.; Bhamidimarri, S. P.; Winterhalter, M. Small-molecule permeation across membrane channels: Chemical modification to quantify transport across OmpF. Angew. Chem., Int. Ed. Engl. 2019, 58, 4737-4741.

(29) Ziervogel, B. K.; Roux, B. The binding of antibiotics in OmpF porin. Structure 2013, 21, 76-87.

(30) Prajapati, J. D.; Kleinekathöfer, U.; Winterhalter, M. How to enter a bacterium: Bacterial porins and the permeation of antibiotics. Chem. Rev. 2021, 121, 5158-5192.

(31) Li, P.; Lin, H.; Mi, Z.; Xing, S.; Tong, Y.; Wang, J. Screening of polyvalent phage-resistant Escherichia coli strains based on phage receptor analysis. Front. Microbiol. 2019, 10, 850.

(32) Kortright, K. E.; Chan, B. K.; Turner, P. E. High-throughput discovery of phage receptors using transposon insertion sequencing of bacteria. Proc. Natl. Acad. Sci. U.S.A. 2020, 117, 18670-18679.

(33) Housden, N. G.; Hopper, J. T. S.; Lukoyanova, N.; RodriguezLarrea, D.; Wojdyla, J. A.; Klein, A.; Kaminska, R.; Bayley, H.; Saibil, H. R.; Robinson, C. V.; Kleanthous, C. Intrinsically disordered protein threads through the bacterial outer-membrane porin OmpF. Science 2013, 340, 1570-1574.

(34) Jansen, K. B.; Inns, P. G.; Housden, N. G.; Hopper, J. T. S.; Kaminska, R.; Lee, S.; Robinson, C. V.; Bayley, H.; Kleanthous, C. 
Bifurcated binding of the OmpF receptor underpins import of the bacteriocin colicin N into Escherichia coli. J. Biol. Chem. 2020, 295, 9147-9156.

(35) Bakelar, J.; Buchanan, S. K.; Noinaj, N. The structure of the $\beta$ barrel assembly machinery complex. Science 2016, 351, 180-186.

(36) Gu, Y.; Li, H.; Dong, H.; Zeng, Y.; Zhang, Z.; Paterson, N. G.; Stansfeld, P. J.; Wang, Z.; Zhang, Y.; Wang, W.; Dong, C. Structural basis of outer membrane protein insertion by the BAM complex. Nature 2016, 531, 64-69.

(37) Tomasek, D.; Rawson, S.; Lee, J.; Wzorek, J. S.; Harrison, S. C.; $\mathrm{Li}$, Z.; Kahne, D. Structure of a nascent membrane protein as it folds on the BAM complex. Nature 2020, 583, 473-478.

(38) Alvira, S.; Watkins, D. W.; Troman, L.; Allen, W. J.; Lorriman, J. S.; Degliesposti, G.; Cohen, E. J.; Beeby, M.; Daum, B.; Gold, V. A.; Skehel, J. M.; Collinson, I. Inter-membrane association of the Sec and BAM translocons for bacterial outer-membrane biogenesis. eLife 2020, 9, No. e60669.

(39) White, P.; Haysom, S. F.; Iadanza, M. G.; Higgins, A. J.; Machin, J. M.; Whitehouse, J. M.; Horne, J. E.; Schiffrin, B.; Carpenter-Platt, C.; Calabrese, A. N.; Storek, K. M.; Rutherford, S. T.; Brockwell, D. J.; Ranson, N. A.; Radford, S. E. The role of membrane destabilisation and protein dynamics in BAM catalysed OMP folding. Nat. Commun. 2021, 12, 4174.

(40) Takeda, H.; Tsutsumi, A.; Nishizawa, T.; Lindau, C.; Busto, J. V.; Wenz, L.-S.; Ellenrieder, L.; Imai, K.; Straub, S. P.; Mossmann, W.; Qiu, J.; Yamamori, Y.; Tomii, K.; Suzuki, J.; Murata, T.; Ogasawara, S.; Nureki, O.; Becker, T.; Pfanner, N.; Wiedemann, N.; Kikkawa, M.; Endo, T. Mitochondrial sorting and assembly machinery operates by $\beta$-barrel switching. Nature 2021, 590, 163-169.

(41) Robinson, J. A. Folded synthetic peptides and other molecules targeting outer membrane protein complexes in Gram-negative bacteria. Front. Chem. 2019, 7, 45.

(42) Kaur, H.; Jakob, R. P.; Marzinek, J. K.; Green, R.; Imai, Y.; Bolla, J. R.; Agustoni, E.; Robinson, C. V.; Bond, P. J.; Lewis, K.; Maier, T.; Hiller, $\mathrm{S}$. The antibiotic darobactin mimics a $\beta$-strand to inhibit outer membrane insertase. Nature 2021, 593, 125-129.

(43) Luther, A.; Urfer, M.; Zahn, M.; Müller, M.; Wang, S.-Y.; Mondal, M.; Vitale, A.; Hartmann, J.-B.; Sharpe, T.; Monte, F. L.; Kocherla, H.; Cline, E.; Pessi, G.; Rath, P.; Modaresi, S. M.; Chiquet, P.; Stiegeler, S.; Verbree, C.; Remus, T.; Schmitt, M.; Kolopp, C.; Westwood, M.-A.; Desjonquères, N.; Brabet, E.; Hell, S.; LePoupon, K.; Vermeulen, A.; Jaisson, R.; Rithié, V.; Upert, G.; Lederer, A.; Zbinden, P.; Wach, A.; Moehle, K.; Zerbe, K.; Locher, H. H.; Bernardini, F.; Dale, G. E.; Eberl, L.; Wollscheid, B.; Hiller, S.; Robinson, J. A.; Obrecht, D. Chimeric peptidomimetic antibiotics against Gram-negative bacteria. Nature 2019, 576, 452-458.

(44) Goyal, P.; Krasteva, P. V.; Van Gerven, N.; Gubellini, F.; Van den Broeck, I.; Troupiotis-Tsailaki, A.; Jonckheere, W.; PéhauArnaudet, G.; Pinkner, J. S.; Chapman, M. R.; Hultgren, S. J.; Howorka, S.; Fronzes, R.; Remaut, H. Structural and mechanistic insights into the bacterial amyloid secretion channel CsgG. Nature 2014, 516, 250-253.

(45) Rouse, S. L.; Hawthorne, W. J.; Berry, J.-L.; Chorev, D. S.; Ionescu, S. A.; Lambert, S.; Stylianou, F.; Ewert, W.; Mackie, U.; Morgan, R. M. L.; Otzen, D.; Herbst, F.-A.; Nielsen, P. H.; Dueholm, M.; Bayley, H.; Robinson, C. V.; Hare, S.; Matthews, S. A new class of hybrid secretion system is employed in Pseudomonas amyloid biogenesis. Nat. Commun. 2017, 8, 263.

(46) Doyle, M. T.; Bernstein, H. D. BamA forms a translocation channel for polypeptide export across the bacterial outer membrane. Mol. Cell 2021, 81, 2000-2012.

(47) Vorobieva, A. A.; White, P.; Liang, B.; Horne, J. E.; Bera, A. K.; Chow, C. M.; Gerben, S.; Marx, S.; Kang, A.; Stiving, A. Q.; Harvey, S. R.; Marx, D. C.; Khan, G. N.; Fleming, K. G.; Wysocki, V. H.; Brockwell, D. J.; Tamm, L. K.; Radford, S. E.; Baker, D. De novo design of transmembrane $\beta$ barrels. Science 2021, 371, No. eabc8182.

(48) Walser, R.; Kleinschmidt, J. H.; Skerra, A.; Zerbe, O. $\beta$-Barrel scaffolds for the grafting of extracellular loops from G-protein-coupled receptors. Biol. Chem. 2012, 393, 1341-1355.
(49) Thulasingam, M.; Damodharan, S.; Madhana Vigneshwari, G.; P. J. Pandaranayaka, E.; Elizabeth Hanna, L.; Usha, R.; Krishnaswamy, S. Characterization of Salmonella typhi OmpC and OmpF porins engineered with HIV-gp41 epitope on the surface loops. Proteins 2017, 85, 657-664.

(50) Chen, T.; Wang, K.; Chi, X.; Zhou, L.; Li, J.; Liu, L.; Zheng, Q.; Wang, Y.; Yu, H.; Gu, Y.; Zhang, J.; Li, S.; Xia, N. Construction of a bacterial surface display system based on outer membrane protein $\mathrm{F}$. Microb. Cell Fact. 2019, 18, 70.

(51) Danoff, E. J.; Fleming, K. G. Aqueous, unfolded OmpA forms amyloid-like fibrils upon self-association. PLoS One 2015, 10, No. e0132301.

(52) Joseph Sahaya Rajan, J.; Chinnappan Santiago, T.; Singaravel, R.; Ignacimuthu, S. Outer membrane protein $\mathrm{C}(\mathrm{OmpC})$ of Escherichia coli induces neurodegeneration in mice by acting as an amyloid. Biotechnol. Lett. 2016, 38, 689-700.

(53) Perchiacca, J. M.; Ladiwala, A. R. A.; Bhattacharya, M.; Tessier, P. M. Structure-based design of conformation- and sequence-specific antibodies against amyloid $\beta$. Proc. Natl. Acad. Sci. U.S.A. 2012, 109, 84-89.

(54) Ladiwala, A. R. A.; Bhattacharya, M.; Perchiacca, J. M.; Cao, P.; Raleigh, D. P.; Abedini, A.; Schmidt, A. M.; Varkey, J.; Langen, R.; Tessier, P. M. Rational design of potent domain antibody inhibitors of amyloid fibril assembly. Proc. Natl. Acad. Sci. U.S.A. 2012, 109, 19965-19970.

(55) Julian, M. C.; Rabia, L. A.; Desai, A. A.; Arsiwala, A.; Gerson, J. E.; Paulson, H. L.; Kane, R. S.; Tessier, P. M. Nature-inspired design and evolution of anti-amyloid antibodies. J. Biol. Chem. 2019, 294, $8438-8451$

(56) Franklin, M. W.; Nepomnyachyi, S.; Feehan, R.; Ben-Tal, N.; Kolodny, R.; Slusky, J. S. Evolutionary pathways of repeat protein topology in bacterial outer membrane proteins. eLife 2018, 7, No. e40308.

(57) El-Khatib, M.; Nasrallah, C.; Lopes, J.; Tran, Q.-T.; Tetreau, G.; Basbous, H.; Fenel, D.; Gallet, B.; Lethier, M.; Bolla, J.-M.; Pagès, J.-M.; Vivaudou, M.; Weik, M.; Winterhalter, M.; Colletier, J.-P. Porin self-association enables cell-to-cell contact in Providencia stuartii floating communities. Proc. Natl. Acad. Sci. U.S.A. 2018, 115, E2220E2228.

(58) Beck, C. M.; Willett, J. L. E.; Cunningham, D. A.; Kim, J. J.; Low, D. A.; Hayes, C. S. CdiA effectors from uropathogenic Escherichia coli use heterotrimeric osmoporins as receptors to recognize target bacteria. PLoS Pathog. 2016, 12, No. e1005925.

(59) Choi, U.; Lee, C.-R. Distinct roles of outer membrane porins in antibiotic resistance and membrane integrity in Escherichia coli. Front. Microbiol. 2019, 10, 953.

(60) Pósfai, G.; Plunkett, G.; Fehér, T.; Frisch, D.; Keil, G. M.; Umenhoffer, K.; Kolisnychenko, V.; Stahl, B.; Sharma, S. S.; de Arruda, M.; Burland, V.; Harcum, S. W.; Blattner, F. R. Emergent properties of reduced-genome Escherichia coli. Science 2006, 312, $1044-1046$.

(61) Gasset-Rosa, F.; Coquel, A.-S.; Moreno-del Álamo, M.; Chen, P.; Song, X.; Serrano, A. M.; Fernández-Tresguerres, M. E.; MorenoDíaz de la Espina, S.; Lindner, A. B.; Giraldo, R. Direct assessment in bacteria of prionoid propagation and phenotype selection by Hsp70 chaperone. Mol. Microbiol. 2014, 91, 1070-1087.

(62) Dam, S.; Pagès, J.-M.; Masi, M. Stress responses, outer membrane permeability control and antimicrobial resistance in Enterobacteriaceae. Microbiology 2018, 164, 260-267.

(63) Giraldo, R. Defined DNA sequences promote the assembly of a bacterial protein into distinct amyloid nanostructures. Proc. Natl. Acad. Sci. U.S.A. 2007, 104, 17388-17393.

(64) Giraldo, R. SynBio and the Boundaries between Functional and Pathogenic RepA-WH1 Bacterial Amyloids. mSystems 2020, 5, e00553-20.

(65) Fernández-Tresguerres, M. E.; Moreno-Díaz de la Espina, S.; Gasset-Rosa, F.; Giraldo, R. A DNA-promoted amyloid proteinopathy in Escherichia coli. Mol. Microbiol. 2010, 77, 1456-1469. 
(66) Fernández, C.; Núñez-Ramírez, R.; Jiménez, M.; Rivas, G.; Giraldo, R. RepA-WH1, the agent of an amyloid proteinopathy in bacteria, builds oligomeric pores through lipid vesicles. Sci. Rep. 2016, 6, 23144.

(67) Pantoja-Uceda, D.; Oroz, J.; Fernández, C.; de Alba, E.; Giraldo, R.; Laurents, D. V. Conformational priming of RepA-WH1 for functional amyloid conversion detected by NMR spectroscopy. Structure 2020, 28, 336-347.

(68) Gasset-Rosa, F.; Giraldo, R. Engineered bacterial hydrophobic oligopeptide repeats in a synthetic yeast prion, $\left[\mathrm{REP}-\mathrm{PSI}^{+}\right]$. Front. Microbiol. 2015, 06, 311.

(69) Molina-García, L.; Giraldo, R. Enabling stop codon readthrough translation in bacteria as a probe for amyloid aggregation. Sci. Rep. 2017, 7, 11908.

(70) Balistreri, A.; Kahana, E.; Janakiraman, S.; Chapman, M. R. Tuning functional amyloid formation through disulfide engineering. Front. Microbiol. 2020, 11, 944.

(71) Saha, S.; Lach, S. R.; Konovalova, A. Homeostasis of the Gramnegative cell envelope. Curr. Opin. Microbiol. 2021, 61, 99-106.

(72) Echeverría, C.; Torres, M. D. T.; Fernández-García, M.; de la Fuente-Nunez, C.; Muñoz-Bonilla, A. Physical methods for controlling bacterial colonization on polymer surfaces. Biotechnol. Adv. 2020, 43, 107586.

(73) Molina-García, L.; Moreno-del Álamo, M.; Botias, P.; MartínMoldes, Z.; Fernández, M.; Sánchez-Gorostiaga, A.; Alonso-del Valle, A.; Nogales, J.; García-Cantalejo, J.; Giraldo, R. Outlining core pathways of amyloid toxicity in bacteria with the RepA-WH1 prionoid. Front. Microbiol. 2017, 8, 539.

(74) Revilla-García, A.; Fernández, C.; Moreno-del Álamo, M.; de Los Ríos, V.; Vorberg, I. M.; Giraldo, R. Intercellular transmission of a synthetic bacterial cytotoxic prion-like protein in mammalian cells. mBio 2020, 11, No. e02937-19.

(75) Rassam, P.; Copeland, N. A.; Birkholz, O.; Tóth, C.; Chavent, M.; Duncan, A. L.; Cross, S. J.; Housden, N. G.; Kaminska, R.; Seger, U.; Quinn, D. M.; Garrod, T. J.; Sansom, M. S. P.; Piehler, J.; Baumann, C. G.; Kleanthous, C. Supramolecular assemblies underpin turnover of outer membrane proteins in bacteria. Nature 2015, 523, $333-336$.

(76) Peterson, J. H.; Plummer, A. M.; Fleming, K. G.; Bernstein, H. D. Selective pressure for rapid membrane integration constrains the sequence of bacterial outer membrane proteins. Mol. Microbiol. 2017, 106, 777-792.

(77) Stenkova, A. M.; Isaeva, M. P.; Shubin, F. N.; Rasskazov, V. A.; Rakin, A. V. Trends of the major porin gene (ompF) evolution: Insight from the genus Yersinia. PLoS One 2011, 6, No. e20546.

(78) Molina-García, L.; Gasset-Rosa, F.; Moreno-del Álamo, M.; Fernández-Tresguerres, M. E.; Moreno-Díaz de la Espina, S.; Lurz, R.; Giraldo, R. Functional amyloids as inhibitors of plasmid DNA replication. Sci. Rep. 2016, 6, 25425.

(79) Datsenko, K. A.; Wanner, B. L. One-step inactivation of chromosomal genes in Escherichia coli K-12 using PCR products. Proc. Natl. Acad. Sci. U.S.A. 2000, 97, 6640-6645.

(80) Hoffmann, S.; Schmidt, C.; Walter, S.; Bender, J. K.; Gerlach, R. G. Scarless deletion of up to seven methyl-accepting chemotaxis genes with an optimized method highlights key function of CheM in Salmonella Typhimurium. PLoS One 2017, 12, No. e0172630.

(81) Molina-García, L.; Gasset-Rosa, F.; Álamo, M. M.-d.; de la Espina, S. M.-D.; Giraldo, R. Addressing intracellular amyloidosis in bacteria with RepA-WH1, a prion-like protein. Methods Mol. Biol. 2018, 1779, 289-312.

(82) Park, H.; Kim, D. E.; Ovchinnikov, S.; Baker, D.; DiMaio, F. Automatic structure prediction of oligomeric assemblies using Robetta in CASP12. Proteins 2018, 86, 283-291. 